\title{
Research on the Oil-Bearing Difference of Bedding Fractures: A Case Study of Lucaogou Formation in Jimsar Sag
}

\author{
Jia Lu $\mathbb{D},{ }^{1}$ Chen Zhang $\mathbb{D}^{2,3}$ Jianhui Zeng $\mathbb{D}^{2,3}$ and Haowei Yuan $\mathbb{D}^{2,3}$ \\ ${ }^{1}$ Faculty of Land and Resource Engineering, Kunming University of Science and Technology, Kunming, China \\ ${ }^{2}$ State Key Laboratory of Petroleum Resources and Prospecting, China University of Petroleum, Beijing, China \\ ${ }^{3}$ College of Geoscience, China University of Petroleum, Beijing, China
}

Correspondence should be addressed to Jianhui Zeng; zengjh@cup.edu.cn

Jia Lu and Chen Zhang contributed equally to this work.

Received 28 January 2021; Accepted 18 May 2021; Published 1 June 2021

Academic Editor: Martina Zucchi

Copyright (C) 2021 Jia Lu et al. This is an open access article distributed under the Creative Commons Attribution License, which permits unrestricted use, distribution, and reproduction in any medium, provided the original work is properly cited.

Lucaogou formation in Jimsar sag is host to large quantities of bedding fractures which are known to play a critical role in the enrichment, accumulation, and efficient development of tight oil. In this paper, we examine and finely characterize the development of the bedding fractures found in the upper and lower sweet spots of Lucaogou formation of tight oil reservoir through field outcrop and core observation, cast thin section analysis, and imaging log recognition and investigate the factors affecting their differentiated oil-bearing by means of inclusion temperature measurement, TOC testing, physical property testing, high-pressure mercury injection, and physical simulation experiment. By comparison with the linear density, bedding fractures are more developed in the lower sweet spot. These fractures occur in parallel to the formation boundary and have small aperture. Most of bedding fractures are unfilled fractures. Among the few types of fractures found there, bedding fractures have the best oil-bearing property, but the oil-bearing can differ from one bedding fracture to another. The factors affecting the differentiated oil-bearing of bedding fractures include the temporal coupling of the formation of these fractures with the hydrocarbon generation of the source rocks and the spatial coupling of the bedding fractures with the source rocks. In terms of temporal coupling, mass hydrocarbon generation in Jimsar sag began in Late Jurassic. Inclusion temperature measurement indicates that the bedding fractures there formed in or after Early Cretaceous. Hence, by matching the mass hydrocarbon generation period of the source rocks with the formation period of the bedding fractures, we discovered that the bedding fractures formed within the mass hydrocarbon generation period, which favored the oil-bearing of these fractures. The spatial coupling is manifested in TOC, porosity, permeability, and pore throat, with TOC being the main controlling factor. For TOC, the higher the formation TOC, the better the oil-bearing property of the bedding fractures. For porosity, subject to the TOC level, if the TOC is adequate, the larger the porosity, the larger the chloroform asphalt "A," accordingly the higher the oil content of the formation, and the better the oil-bearing property of the bedding fractures developed therein. In this sense, in terms of spatial coupling, TOC constitutes the main controlling factor of the oil-bearing property of bedding fractures.

\section{Introduction}

Over the past years, as the exploitation of conventional oil and gas intensifies, global oil and gas exploration and development has gradually shifted toward unconventional oil and gas resources. Tight oil, as a very important unconventional oil and gas resource, is a very realistic alternative for conventional oil [1-3]. Inside tight reservoirs, fractures not only provide seepage channels for oil and gas migration, but also serve as important oil and gas storage spaces. They are one of the important factors affecting the oil-bearing property of tight oil reservoirs. For this reason, studying the natural fractures in tight reservoirs is highly instructive for the efficient development of tight oil reservoirs [4]. Bedding fractures are strongly associated with hydrocarbon generation and migration in tight reservoirs. Previous authors have 
made extensive studies into structural fractures, but few have paid attention to bedding fractures.

Previous studies have tended to categorize bedding fractures as a part of structural fractures or diagenetic fractures [5-8]. Regarding the origin of bedding fractures, assumptions include tectonic origin [9-11], hydrocarbon generation-acid expulsion-dissolution $[10,12]$, pressure fracturing of authigenic fluids inside reservoirs [13, 14], and tectonic plus hydrocarbon generation-acid expulsion $[15,16]$. The earliest assumption of the origin of bedding fractures in tight reservoirs was the self-generation-selfstorage-postfracturing of oil and gas proposed by $\mathrm{Wu}$ and Yin [17], whose target formation was Upper Shaximiao formation in Xinchang of western Sichuan where the oil and gas reservoirs are tight sandstone reservoirs. At the time when natural gas enriched and accumulated in Upper Shaximiao formation, the reservoirs were conventional natural gas reservoirs. Over time, after reservoir tightening and tectonic processes, Upper Shaximiao formation became a tightly closed system. When the pressure of the natural gas and other fluids inside the formation is greater than the breaking strength of the bedding plane of tight sandstone, the bedding plane can be pressed open by the natural fluids in the closed body to form bedding fractures $[18,19]$. Later on, their assumption was echoed by some other authors, who suggested that for a bedding to break open, there should exist a critical strength. Only when the stress acting on the bedding boundary is greater than this critical strength will the bedding be pressed open to form bedding fractures [20-22]. Among the many discussions supporting the tectonic origin of bedding fractures $[12,18,20-22]$, one common belief is that water flow direction, lithologic alternation, sand body distribution, and sedimentary processes such as sedimentary facies control the development of beddings [20,22], while subsequent tectonic processes, such as faulting, compression by horizontal in situ stress, and basin uplifting, caused the weak plane of the beddings to break and form bedding fractures. As to hydrocarbon generation-acid expulsion, it is commonly believed to be an auxiliary factor, since dissolved pores are present on some of the bedding planes. The hydrocarbon generation-acid expulsion of organic matter is obviously a pore adder for the formations [23]. The dissolution effect of organic acids when migrating along the bedding boundary [24] is possibly the main controlling factor for the formation of bedding fractures. The assumption of tectonic plus dissolution origin includes for the interaction among various factors. It suggests that single factors can become the main controlling factor of the formation of bedding fractures in a specific historic period or a certain block, such as fracture creation by tectonic stress, the dissolution of acid fluids, or the release of abnormally high pressure. Some authors have conducted research specific to the fractures developed in Lucaogou formation in Jimsar sag [19, 25-27]. They discovered that tectonic processes are quite weak in this area. Hence, for the formation of bedding fractures, the hydrocarbon generation-acid expulsion bedding plane of the source rocks makes play a critical role. The acidic matter generated by the hydrocarbon generation of the source rocks may have migrated along the already formed bedding boundary. The joint action of tectonic processes with the dissolution effect of hydrocarbon generation-acid expulsion is more likely to have caused the formation of bedding fractures.

Among existing studies around bedding fractures and oil and gas migration, the opinions of most of the authors are advocating and superficial, assuming that bedding fractures are conducive to tight oil enrichment and occurrence. For example, in 2016, in a study of Chang6 reservoir in Heshui of Eros Basin, Yang and his colleagues discovered that bedding fractures, massive beddings, and graded beddings exist on millimeter scale in the tight reservoirs there; the development of bedding fractures has led to tight oil enrichment, and massive beddings are the most conducive to oil enrichment $[28,29]$. In 2017, Zhang et al. noticed that bedding fractures are commonly present in tight reservoirs. Preliminary core observation also revealed that these fractures play a critical role in tight oil accumulation and enrichment. They recommended employing more effort in the research of bedding fractures, especially their aperture and closure, as well as their oil filling and enrichment efficiency [26]. They also put forward some ideas and methods in this respect for the first time. Some other authors have looked at how bedding fractures affect tight oil migration and accumulation. They deemed that the extensive development of bedding fractures increases the saturation of movable oil in tight oil reservoirs, thus contributing positively to tight oil migration and occurrence. For example, Dou et al. investigated how the Jurassic bedding fractures in Yongjin of Junggar Basin affect the reservoirs there. They concluded that bedding fractures bridge the matrix pores, provide seepage channels for oil and gas, and enhance the permeability of low-permeability reservoirs. Besides, the development of bedding fractures also helps increase the number of dissolution pores and further expands the storage spaces [30]. Bai et al. and Wang et al. yielded roughly the same conclusion in their study of the doublemedium reservoirs in the tight sandstone of Chang3 member of Triassic Yanchang formation in Junggar Basin: the number of bedding fractures present has a significant impact on the saturation of movable oil. That is, the more developed the bedding fractures, the higher the saturation of the movable oil in the reservoir. Bedding fractures are a great contributor for tight oil accumulation and enrichment [31, 32]. However, despite the wide consensus that fractures make a great difference to oil and gas migration, studies specific to the relationship between bedding fractures and tight oil accumulation have rarely been read. In general, many findings have been made with respect to fractures in conventional reservoirs [33,34] and low-permeability reservoirs [35]. The few reports on bedding fractures in tight oil reservoirs that do exist are mostly descriptive, qualitative studies, let alone research specific to the relationship between bedding fractures and tight oil accumulation, especially the oil-bearing difference and oil accumulating pattern of bedding fractures.

Lucaogou formation in Jimsar sag, Junggar Basin, has a rich stock of tight oil. In fact, it is a very important tight oil reservoir in China $[19,36,37]$. Over the past few years, industrial oil flows have been yielded from a number of 


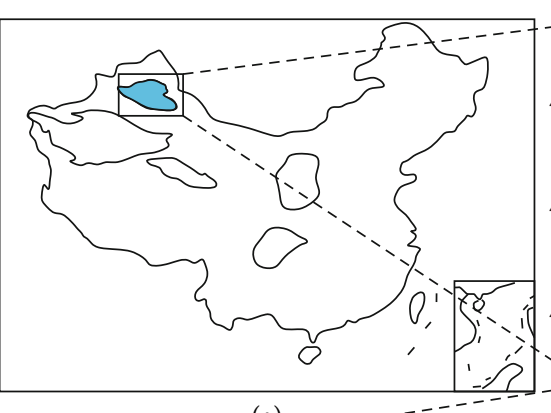

(a)

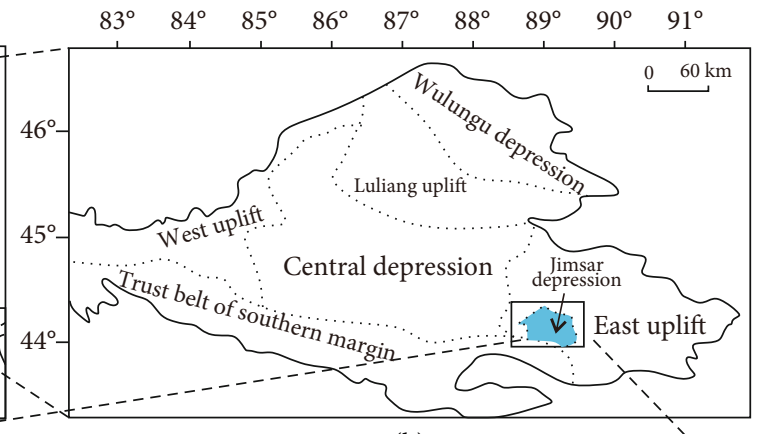

(b)

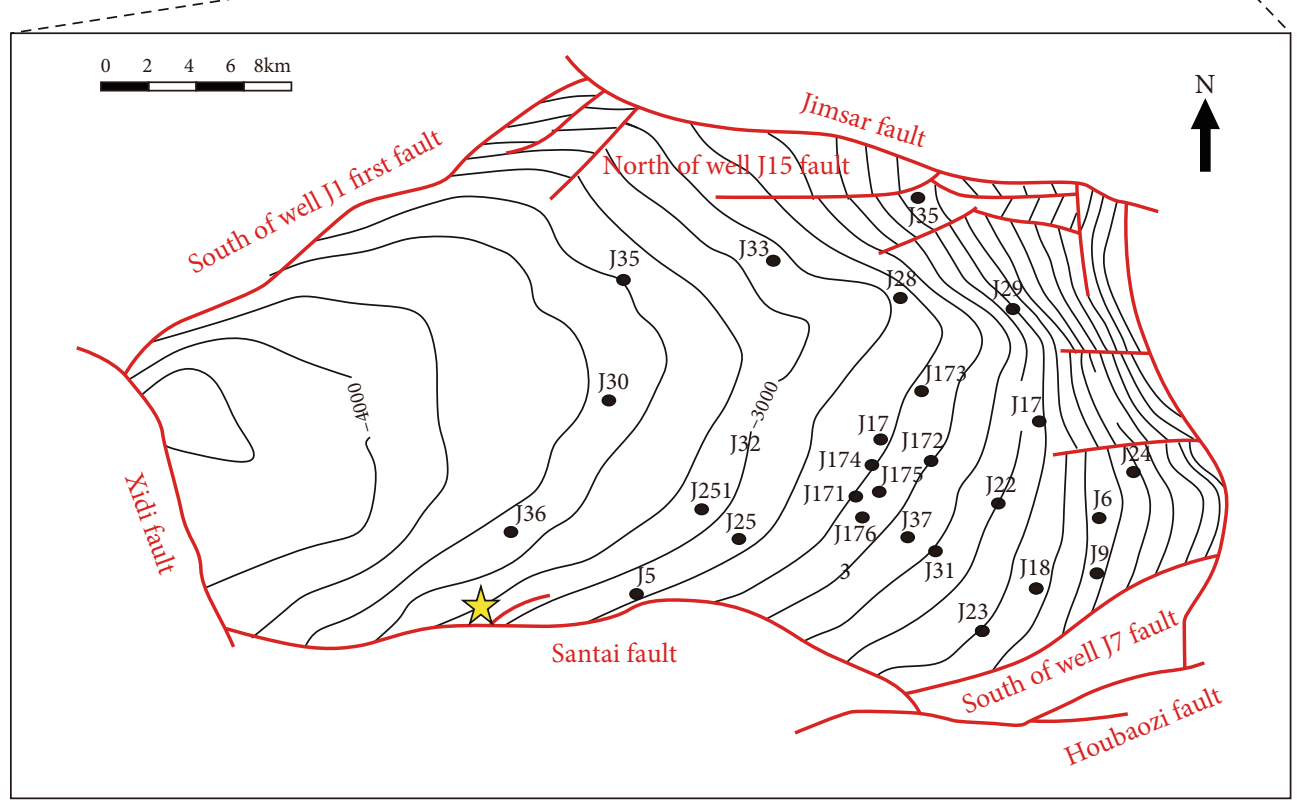

(c)

$\longleftarrow$ Fault
$\square$ Borehole location

$\longrightarrow$ Structure contour

स. Field outcrops

FIgure 1: The Tectonic setting map of Jimsar sag [42].

boreholes in Jimsar sag, demonstrating vast exploration and development potential $[1,4,19]$. Tight oil reservoirs are low-porosity, low-permeability reservoirs. For the commercial development of tight oil, the enrichment and development of fractures is of fatal significance. The fractures in reservoirs, as both important oil and gas storage spaces and seepage channels, are an important determinant for the mobility of oil and gas $[6,7,11]$. The presence of natural fractures is conducive to oil and gas accumulation $[1-3,7,8]$ and to the formation of sweet spots in tight oil reservoirs. Lucaogou formation in Jimsar sag is host to large quantities of bedding fractures, yet research on the relationship between the bedding fractures in tight oil reservoirs and tight oil accumulation is still quite weak $[19,20,36]$. For this reason, investigating the development characteristics and oil-bearing property of bedding fractures and their impact on tight oil accumulation is both theoretically and practically useful for understanding the development characteristics of Lucaogou formation tight oil reservoir, evaluating its development potential and feasibility, and looking for engineering development sweet spots.
In the following sections, we are going to elaborate on and finely characterize the development of bedding fractures in the upper and lower sweet spots of Lucaogou formation tight oil reservoir, discuss the factors affecting their differentiated oil-bearing, determine their oil accumulating pattern, and eventually establish the tight oil accumulation pattern of the bedding fractures in the study area.

\section{Geological Setting}

Junggar Basin is a typical giant inland superimposed basin located at the junction between Kazakhstan plate, Siberia plate, and Tarim plate [38-40]. It is well known for its rich oil and gas resources. Within the basin, Jimsar sag contains a large stock of tight oil that is well worth exploration and development $[37,41]$. Jimsar sag is located in the southeast margin of Junggar Basin, covering an area of approximately $1300 \mathrm{~km}^{2}$. Tectonically, this basin has very distinct boundary features (Figure 1). Its north, west, and south are controlled by faults, while its east transitions into Guxi uplift [37, 40, 41]. Since basin evolution began in Permian, Jimsar sag has 

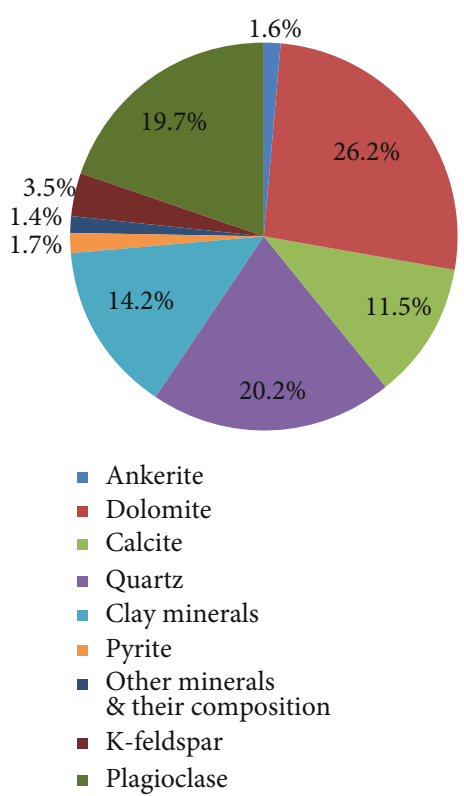

FIgURe 2: Mineral composition fan chart of Lucaogou formation.

undergone a number of tectonic movements. Among them, the one most closely related to its present tectonic architecture is the Himalayan movement in Cenozoic, when the uplifting of its east boundary turned the sag into a dustpanlike monocline that is high in the east and low in the west, with formation dip angle of $3^{\circ}-5^{\circ}$ for the main part and no obvious faulting inside $[26,41]$.

From bottom to top, Lucaogou formation can be divided into two members: first member $\left(\mathrm{P}_{2} \mathrm{l}_{1}\right)$ and second member $\left(\mathrm{P}_{2} \mathrm{l}_{2}\right)$ of Lucaogou [42]. Each of the two members can be further divided into two sublayers. Inside Lucaogou formation, there are two sweet spots. The upper sweet spot lies in the second sublayer of the second member of Lucaogou $\left(\mathrm{P}_{2} \mathrm{l}_{2}{ }^{2}\right)$. This sweet spot mainly sits in the center of the sag and the slope location in the east, covering an area of approximately $398 \mathrm{~km}^{2}$. Its thickness spans from 0 to $45 \mathrm{~m}$ with an average of $37.2 \mathrm{~m}$. The lower sweet spot sits in the second sublayer of the first member of Lucaogou $\left(\mathrm{P}_{2} \mathrm{l}_{2}{ }^{1}\right)$. This sweet spot is widely distributed across the area, covering an area of approximately $1278 \mathrm{~km}^{2}$. Its thickness spans from 0 to $65 \mathrm{~m}$ with an average of $50 \mathrm{~m}$. The mineral composition of the Lucaogou formation rocks is complicated, and most of the rocks are lithologically transitional $[36,43]$. High-content minerals in the Lucaogou formation rocks include dolomite, quartz, and plagioclase, which account for $26.2 \%, 20.2 \%$, and $19.7 \%$, respectively, and $66.1 \%$ together. Calcite and clay minerals account for $11.5 \%$ and $14.2 \%$, respectively, and $25.7 \%$ together. Other minerals account for $8.2 \%$ (Figure 2). In general, the observed lithologies can be grouped into three categories: mudstone, carbonate rock, and siltstone.

The entire Lucaogou formation consists of saline lake facies dark-colored, fine-grained sediments [44]. Taking the maximum flooding surface as the boundary, the formation can be divided into an upper member (second member of Lucaogou) and a lower member (first member of Lucaogou). The upper member is a transgressive sedimentary system as a whole, while the lower member is a regressive sedimentary system as a whole. The sedimentary facies type of Lucaogou formation at large is lacustrine delta. For the second member of Lucaogou $\left(\mathrm{P}_{2} \mathrm{l}_{2}\right)$, the sediment supply mainly came from the southeast. The majority of the terrestrial clastic materials were injected from the south of the sag. The main sedimentary facies is shore-shallow lake facies. The microfacies types include sandy bar, dolomite mudflat, sandy beach, dolomite sandflat, and shallow lake mud. For the first member of Lucaogou $\left(\mathrm{P}_{2} \mathrm{l}_{1}\right)$ at large, the sediment supply came from two directions. In the south, deltaic sediments were adequately supplied. The deposited sand bodies stand in great thicknesses. The microfacies types in this member include distal bar, sheet sand, sandy beach, and shallow to semideep lake mud.

\section{Characteristics of Bedding Fractures}

Bedding fractures are the most frequently found type of fractures in Jimsar sag. Statistical analysis of the development characteristics, oil-bearing property, and horizontal distribution of the bedding fractures in the study area is the basis for examining these fractures. Extensive statistics, documentation, and analysis were conducted on the quantity, development characteristics, and oil-bearing property of these fractures through field outcrop observation, core observation, thin section observation, and imaging log recognition. On this basis, the overall development of the bedding fractures in the study area was identified and finely characterized.

3.1. Characteristics of Field Outcrops. Fracture observation and description on field formation outcrops is a fairly straightforward means of fracture research. It offers a systematic understanding of the vertical distribution of fractures, consequently a general idea of the development of fractures inside the formation. The study area Jimsar sag in Junggar Basin is simply structured dustpan-like sag that is faulted in the west and onlapped in the east. Without considering the influence of weathering, outcrop fractures can give a true picture of the development conditions of fractures underground. For the present study, field outcrops were observed across the oil shale section of Baoming Mining $10 \mathrm{~km}$ southeast of Santai county of Jimsar county, Xinjiang (Figure 1(c)). The target formation was Lucaogou formation. In general, the exposed part of the formation consists of very thick black oil shale that contains silty mudstone. The exposure dip angle is $70^{\circ}-80^{\circ}$. Overall, the section has undergone a level of weathering. However, our observation was mainly focused on the bedding fractures developed therein (Figure 3(a)).

By observing the Lucaogou formation outcrop, we found that bedding fractures are the most frequently found type of fractures in Lucaogou formation-they are actually the prevailing type of fractures there. In the photographs, the fractures occurring roughly in parallel to the formation plane are mostly bedding fractures, while those straighter ones intersecting with the formation plane at large angles are mostly structural fractures (Figures 3(a) and 3(b)). The densely distributed bedding fractures and the groups of structural fractures developed there have cut the rock layers 


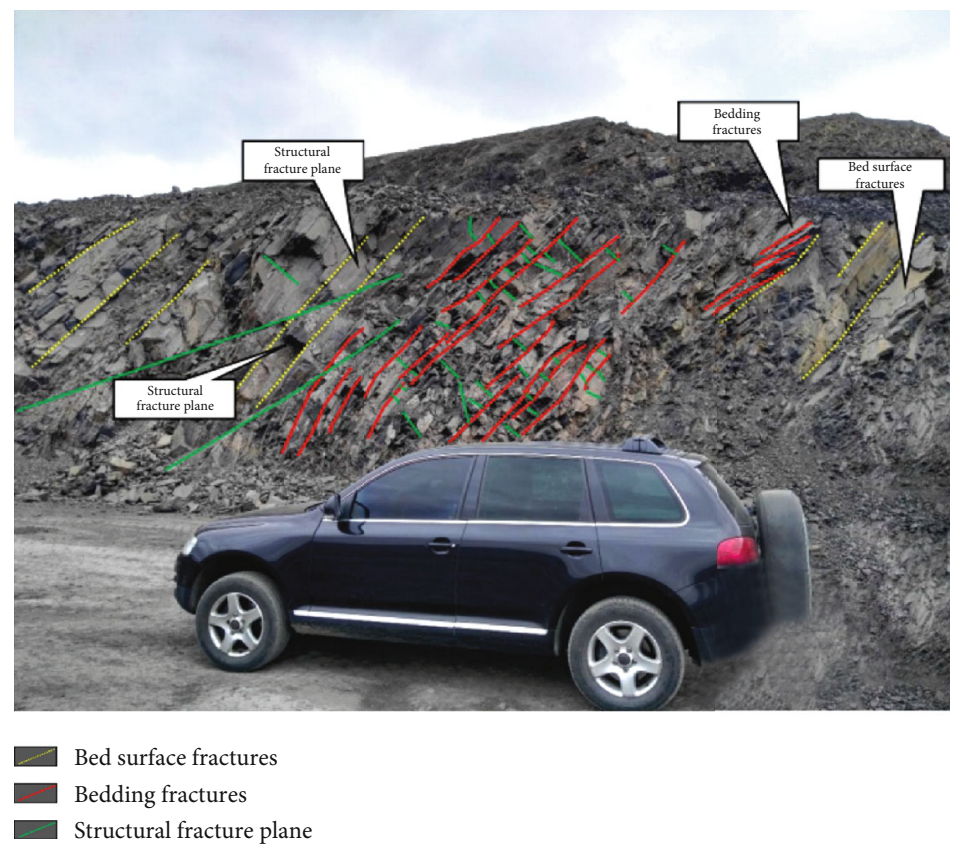

(a)

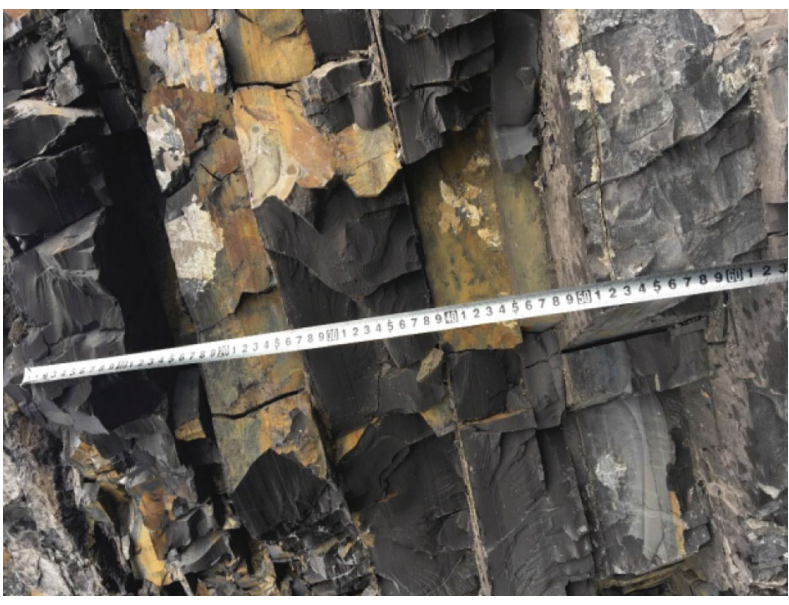

(b)

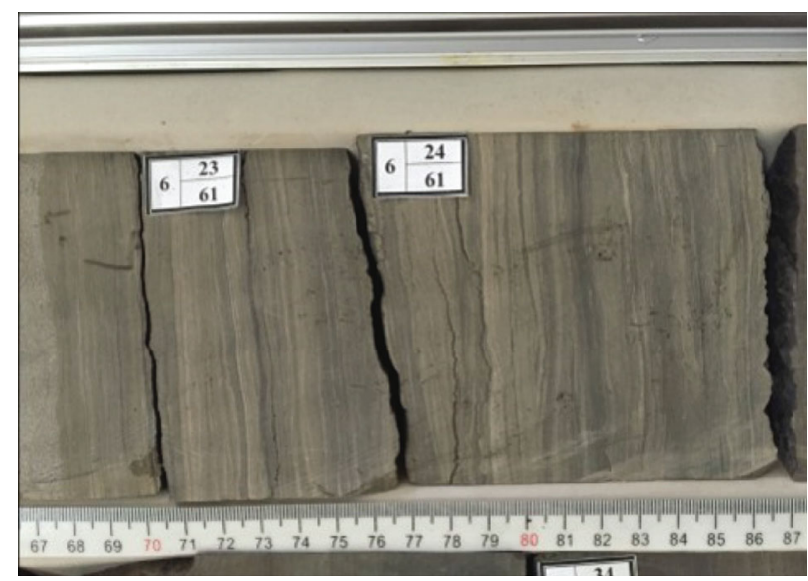

(c)

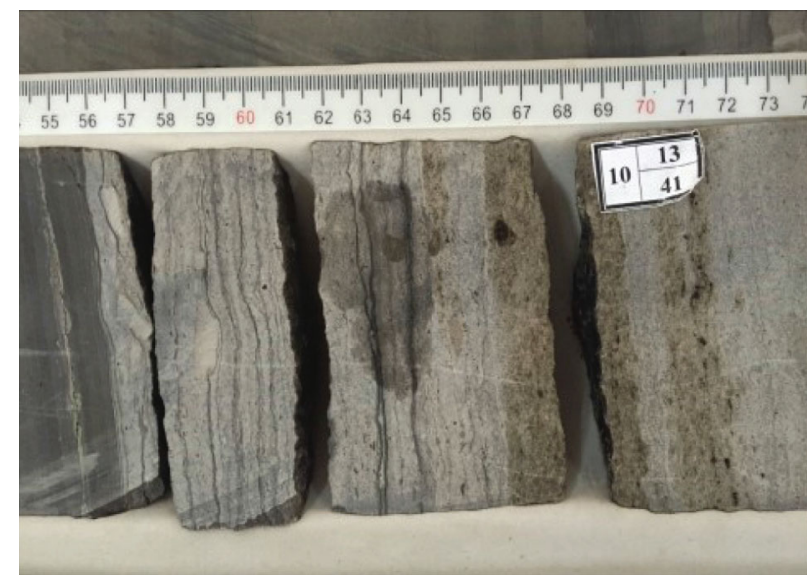

(d)

Figure 3: (a) Macroscopic photograph of Lucaogou outcrop $10 \mathrm{~km}$ southeast of Santao town of Jimsar county, Xinjiang; (b) local photograph of Lucaogou outcrop $10 \mathrm{~km}$ southeast of Santai town of Jimsar county, Xinjiang; (c, d) core photographs of bedding fractures in Lucaogou formation, Jimsar sag. 
into broken rhombic fragments. For the large-thickness rock layers, the cutting disruption is not so intense and the formation is more complete. Lithologically, the exposed stratum is composed of mud shale, with occasional presence of silty mudstone or dolomitic rocks. Some of the bedding fractures have been filled by gypsum or calcite. The filling thickness is very small, roughly $1-3 \mathrm{~mm}$. Closer to the section, a further look at the outcrop will find that lamina is highly developed in the formation, with a density of approximately $5-10 / \mathrm{cm}$ (Figure 3(b)). Smaller-scale bedding fractures are also densely distributed, with approximately 4-10 bedding fractures per 10 centimeters, and most of them are half-filled or filled ones (Figure 3(b)). In summary, the most intuitive feature of the Lucaogou formation outcrop is the high development of formation beddings and the extensive presence of bedding fractures.

3.2. Characteristics of Cores. To obtain a better understanding of the development of fractures in the formation, compared with field outcrop research, direct observation, description, and statistics of fractures using formation cores are very effective methods. As cores have not been exposed to weathering denudation on earth's surface, they give a more realistic picture of fracture development in the rock layers underground. Extensive core observation was carried out in the core library of Xinjiang Oilfield. From these photographs, we can easily see that the bedding fractures typically occur in parallel or almost in parallel to the bedding plane (Figures 3(c) and 3(d)). They generally formed at the interface between strata of different lithologies, and their apertures are limited. Some of the cores are badly disrupted by bedding fractures, which cut off the cores transversely, breaking them into separate segments. The majority of the bedding fractures have poor filling property and are either unfilled or half-filled. The filling materials are generally pelite, calcite, or asphalt. The oil-bearing property of the bedding fractures is commonly good. Oil immersion and oil spotting are extensively observed.

3.3. Characteristics of Thin Sections under Microscope. 86 samples were collected from 24 exploration wells in the middle Permian Lucaogou formation in southeastern Junggar Basin, China. Generally, the bedding fractures observed in cast thin sections and scanning electron microscopy (SEM) are microscale fractures. They are therefore referred to as microfractures. Under thin sections, the bedding fractures generally occur along the lamina. Their lithology usually differs between the upper and lower layers, and they will bypass mineral particles. We can observe the bedding fractures in argillaceous siltstone, mudstone, dolomitic siltstone, and gray sandstone (Figure 4). The bedding fractures have small aperture, limited extension, and large magnification. Morphologically, these fractures are not as straight as they appear on the cores. Instead, they will make curved extension. The extent of extension is not as large, and they will pinch out. The aperture of the bedding fractures is $0.1-5 \mu \mathrm{m}$. The length is $0.1-10 \mathrm{~mm}$. The bedding fractures are mostly unfilled ones. For the filled ones, the filling degree is roughly $20 \%$, leaving a large empty space (Figure 4). The filling materials include some pelite, calcite, and quartz.

On the microscale, the quantity of bedding fractures is modest. The fractures observed include not only bedding fractures, but also other types of fractures such as structural fractures and dissolution fractures. The bedding fractures observed are rated higher than pore throat in size. They constitute good oil and gas migration channels. In the study area, micro bedding fractures-a kind of microfracture-are also present. However, microfractures are a separate research hotspot, and the present study is more focused on macro bedding fractures.

\section{Fine Characterization of Bedding Fractures}

Fine characterization of fractures, namely, fine, detailed description of the characteristics of fractures, typically uses qualitative and quantitative parameters to characterize and reflect the development of fractures [45, 46]. As bedding fractures are fractures that formed by rupture along the beddings and occur roughly in parallel to the formation, their strike and dip angle are roughly the same as the strike and dip angle of the formation. In this consideration, our characterization of bedding fractures herein is made mainly with respect to the density, aperture, and filling property of bedding fractures.

4.1. Linear Density of Bedding Fractures. Fracture density is an important parameter for characterizing the development quantity of fractures $[47,48]$. The linear density of fractures, namely, the number of fractures per unit of length, is calculated by the formula below:

$$
D_{\mathrm{lf}}=\frac{n}{l}
$$

where $n$ is the number of fractures in the measured interval, $l$ is the length of the measured interval, and $D_{\text {lf }}$ is the linear density of fractures in the measured interval. The linear densities of the fractures present in the study area were counted and calculated. Data used for that purpose mainly included imaging log data, which are highly continuous and can provide a full, more objective view of the basic conditions of fracture development on a large scale. Fullbore Formation MicroImager (FMI) is a recently developed new logging technology. The formation information obtained with this technology is more intuitive and provides more precise measurement results [49]. In an FMI diagram, the color represents the resistivity of the borehole wall. High-resistivity portions are marked in white while low-resistivity portions are marked in black. The imaging log data are displayed as individual pictures. Therefore, the results are more intuitive and more convenient for investigation. FMI has already demonstrated satisfactory application results in determining the formation and fracture attitude and recognizing fractures, especially in the development and exploration of complicated oil and gas reservoirs [45, 47, 48, 50].

In imaging logs, fractures undulate as sinusoidal curves. However, our focus herein is mainly on bedding fractures. 


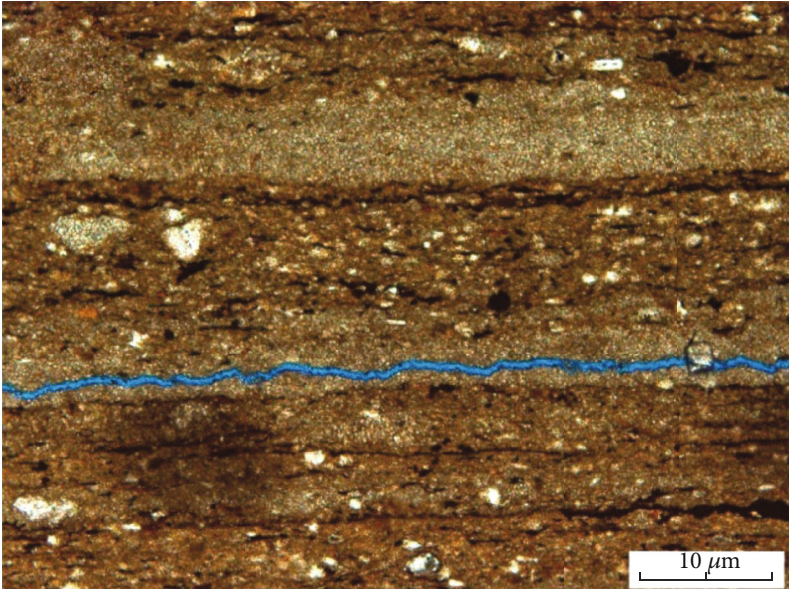

(a)

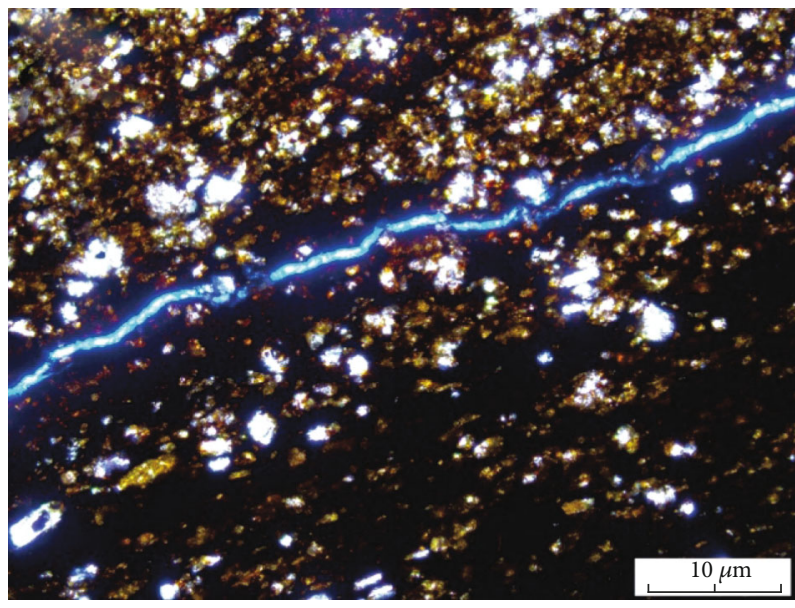

(c)

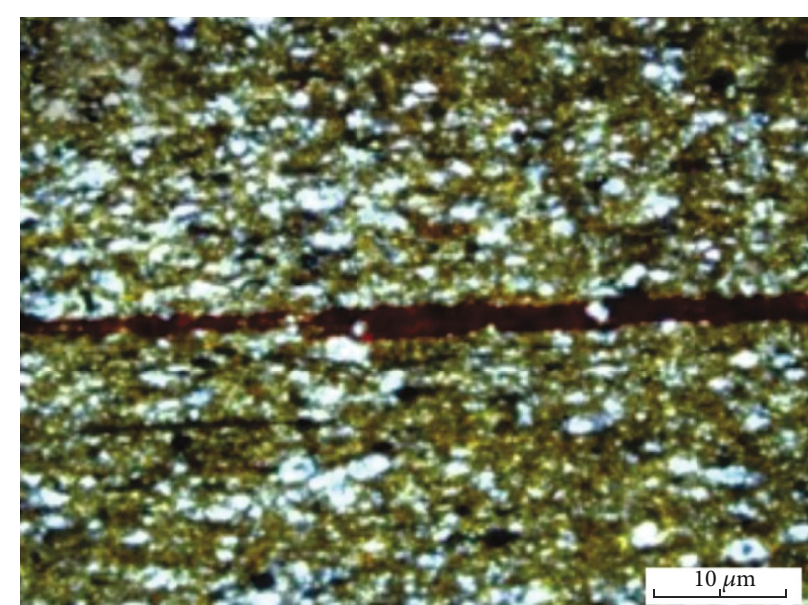

(b)

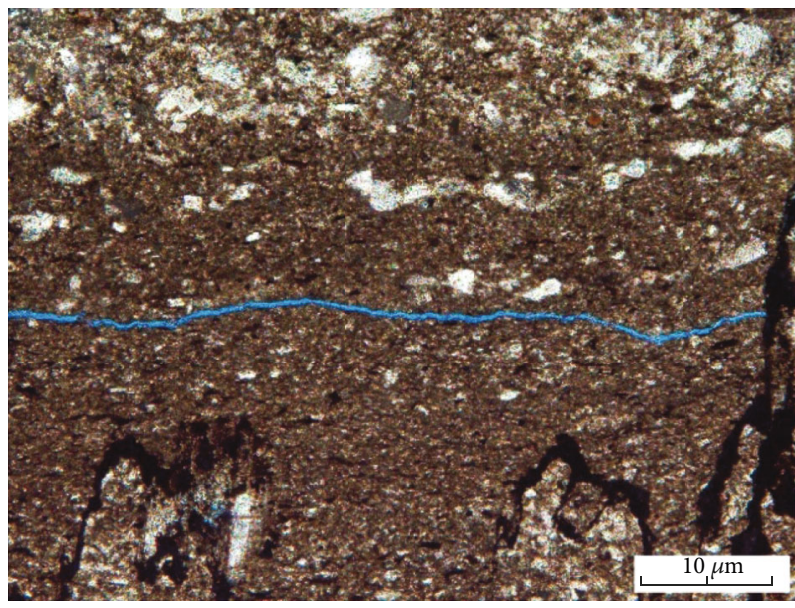

(d)

FIGURE 4: Photographs of bedding fractures in casting thin sections of rocks from Lucaogou formation in Jimsar sag. (a) Ji31, argillaceous siltstone, $2730.2 \mathrm{~m}$; (b) Ji37, mudstone, 2853.9 m; (c) Ji251, dolomitic siltstone, $3769.3 \mathrm{~m}$; (d) Ji251, gray sandstone, $3606.5 \mathrm{~m}$.

Compared with structural fractures, the sinusoidal curve undulation of bedding fractures in imaging log diagrams is smaller. Their aperture is mostly smaller than that of structural fractures. Bedding fractures are approximately parallel to the bedding plane, while structural fractures mostly penetrate the bedding plane. On imaging log diagrams, the bedding fractures in the study area present themselves as low-angle, continuous, dense, and dark fine strips with the same attitude. They also look obviously darker than the adjacent bedding planes due to either the presence of organic matter inside them or the intrusion of drilling fluid (Figures 5(a)-5(c)).

The locations of fractures were determined according to the signatures of fractures in the imaging log data and verified against real cores (Figure 5(d)). The result showed good matching. According to the imaging log data, microscopically, Lucaogou formation is host to mainly structural fractures and bedding fractures, with bedding fractures existing in the largest quantity.

The fractures in the upper and lower sweet spots were, respectively, counted according to the imaging log recognition result. Although the bedding fractures recognized by imaging logs were verified against real cores, there were still instances where beddings were misrecognized as bedding fractures. However, as a bedding plane is a structurally weak plane and locations with excessive beddings can easily rupture to produce bedding fractures in subsequent tectonic movement, the number of beddings in a formation is positively correlated with the number of bedding fractures therein. The number of bedding fractures measured by imaging log data is representative. It can reflect the development of bedding fractures in the formation on the macroscale.

Fractures present in the upper sweet spot were extensively recognized and counted according to the FMI data and some core data of 17 boreholes therein. Table 1 gives the counting result for the upper sweet spot. There, a total of 1468 bedding fractures were recognized. Their average linear density is $2.23 / \mathrm{m}$.

Fractures present in the lower sweet spot were counted and calculated according to the FMI data and some core data of 9 boreholes therein. Table 2 gives the counting result for the lower sweet spot. A total of 1147 bedding fractures were recognized in the lower sweet spot of the study area. Their average linear density is $2.65 / \mathrm{m}$. 


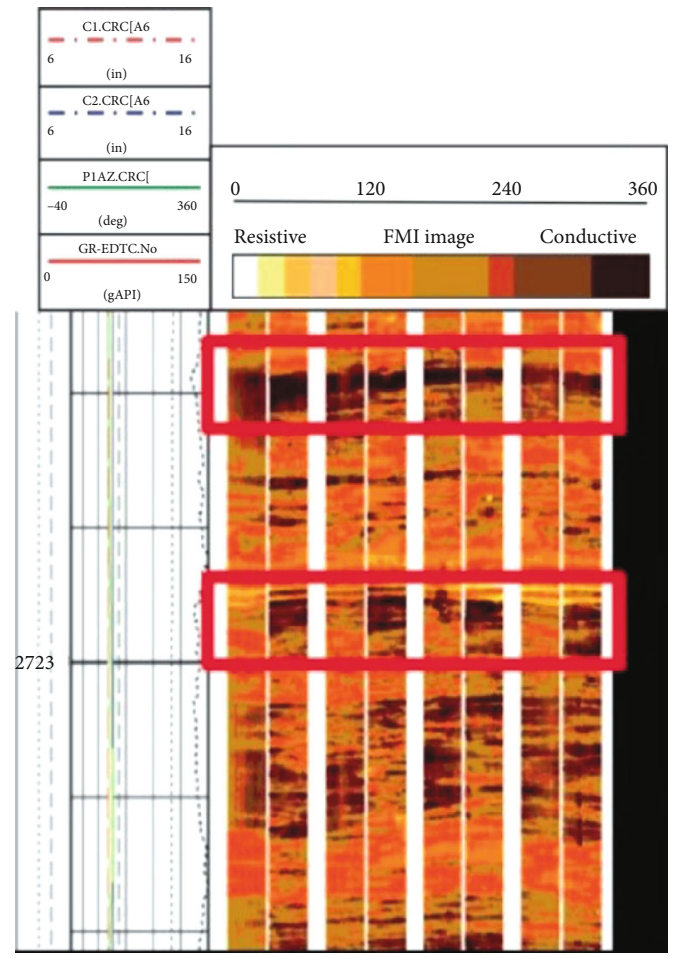

(a)

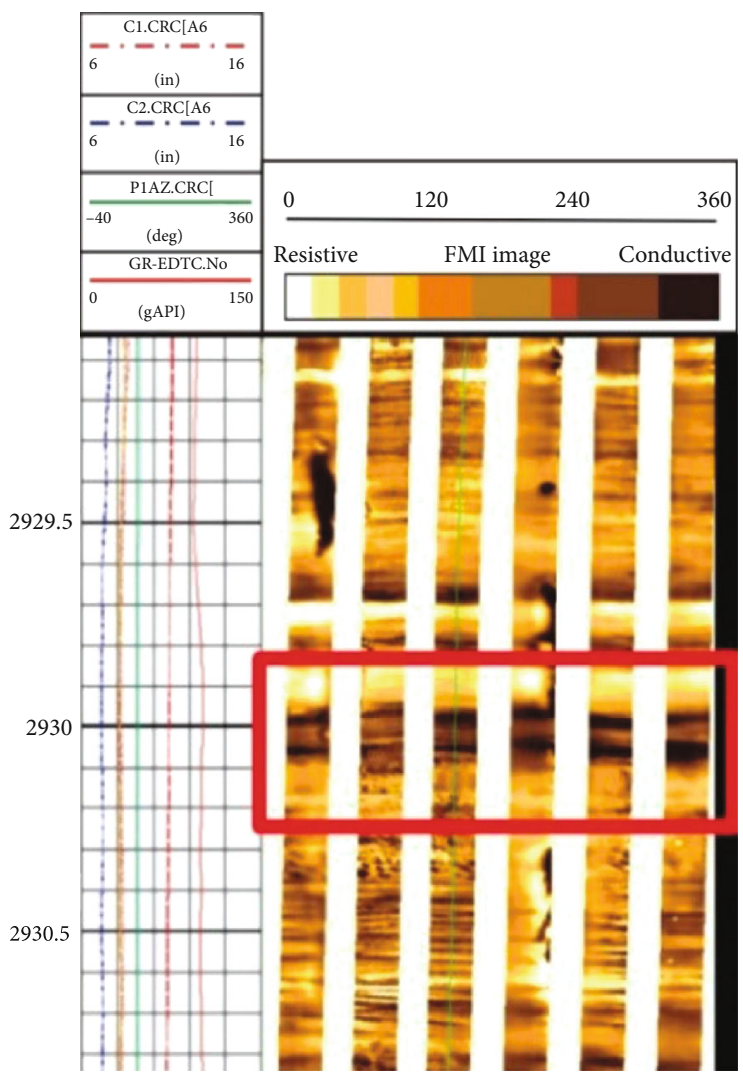

(c)

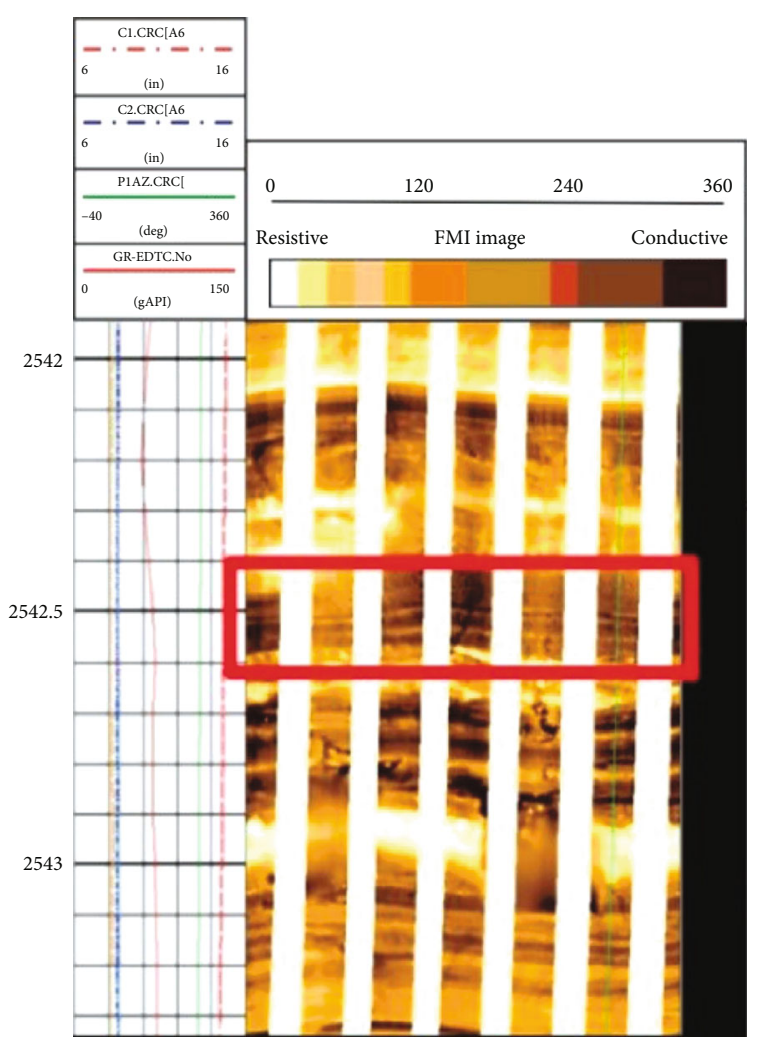

(b)

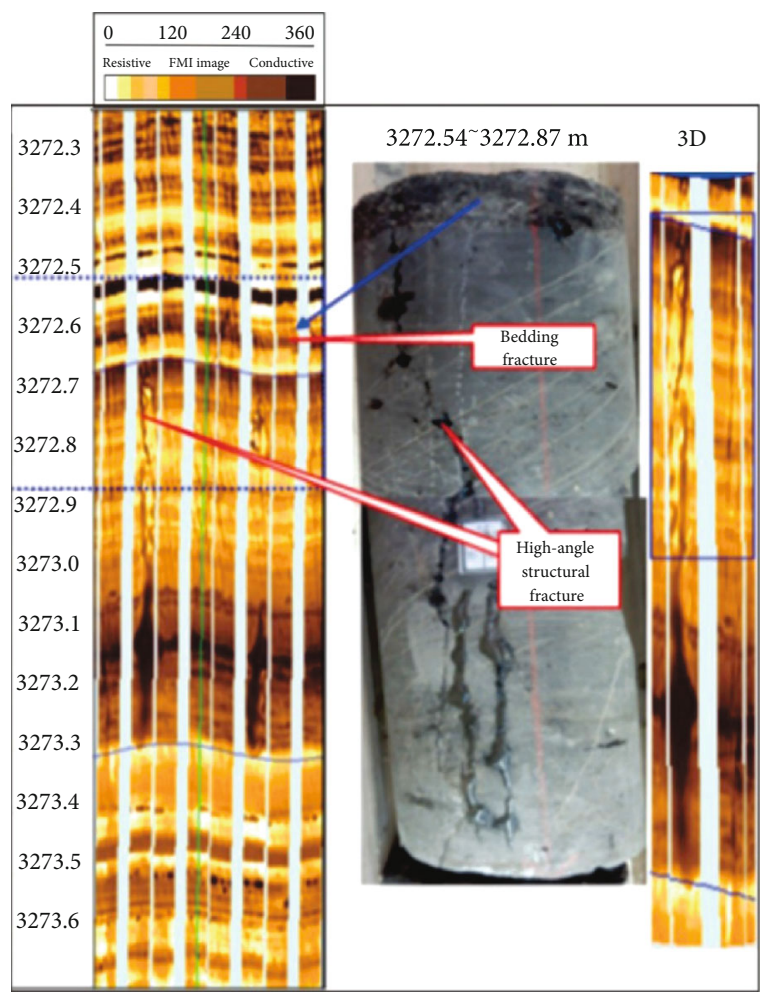

(d)

FIGURE 5: Imaging log identification diagrams of bedding fractures in Lucaogou formation in Jimsar sag. (a) Ji31, 2722.9 m; (b) Ji22, 2542.8 m; (c) Ji172, 2930 m. Note: (d) Ji174, 3272.54-3272.87 m, carbonaceous mudstone. 
TABLE 1: Statistic of linear density of bedding fractures in the upper sweet spot of Lucaogou formation in Jimsar sag.

\begin{tabular}{lccccc}
\hline $\begin{array}{l}\text { Borehole } \\
\text { name }\end{array}$ & $\begin{array}{c}\text { Statistical initial } \\
\text { depth }(\mathrm{m})\end{array}$ & $\begin{array}{c}\text { Statistical cutoff } \\
\text { depth }(\mathrm{m})\end{array}$ & $\begin{array}{c}\text { Statistical } \\
\text { thickness }(\mathrm{m})\end{array}$ & $\begin{array}{c}\text { No. of bedding } \\
\text { fractures }\end{array}$ & $\begin{array}{c}\text { Linear density of bedding fracture } \\
\text { (fractures/m) }\end{array}$ \\
\hline Ji172 & 2917.49 & 2955.67 & 38.18 & 117 & 3.06 \\
Ji173 & 3077.65 & 3116.03 & 38.38 & 79 & 2.06 \\
Ji174 & 3115.20 & 3152.40 & 37.20 & 128 & 3.44 \\
Ji176 & 3022.64 & 3063.03 & 40.39 & 97 & 2.40 \\
Ji22 & 2540.07 & 2575.90 & 35.83 & 59 & 1.65 \\
Ji23 & 2318.58 & 2379.34 & 60.76 & 83 & 1.37 \\
Ji25 & 3393.80 & 3429.70 & 35.90 & 41 & 2.14 \\
Ji27 & 2281.84 & 2316.81 & 34.97 & 87 & 2.87 \\
Ji29 & 2336.66 & 2370.10 & 33.44 & 96 & 1.48 \\
Ji30 & 4018.80 & 4054.60 & 35.80 & 53 & 2.24 \\
Ji31 & 2707.64 & 2749.24 & 41.60 & 93 & 2.30 \\
Ji32 & 3548.61 & 3596.02 & 47.41 & 109 & 1.28 \\
Ji33 & 3517.86 & 3568.04 & 50.18 & 64 & 2.39 \\
Ji34 & 3651.76 & 3691.57 & 39.81 & 95 & 1.73 \\
Ji35 & 3972.97 & 3985.13 & 12.16 & 21 & 3.42 \\
Ji36 & 4117.00 & 4150.00 & 33.00 & 113 & 3.12 \\
Ji37 & 2829.39 & 2871.97 & 42.58 & 133 & \\
\hline
\end{tabular}

TABLE 2: Statistic of linear density of bedding fractures in the lower sweet spot of Lucaogou formation in Jimsar sag.

\begin{tabular}{lccccc}
\hline $\begin{array}{l}\text { Borehole } \\
\text { name }\end{array}$ & $\begin{array}{c}\text { Statistical initial } \\
\text { depth }(\mathrm{m})\end{array}$ & $\begin{array}{c}\text { Statistical cutoff } \\
\text { depth }(\mathrm{m})\end{array}$ & $\begin{array}{c}\text { Statistical } \\
\text { thickness }(\mathrm{m})\end{array}$ & $\begin{array}{c}\text { No of bedding } \\
\text { fractures }\end{array}$ & $\begin{array}{c}\text { Linear density of bedding fracture } \\
\text { (fractures/m) }\end{array}$ \\
\hline Ji174 & 3262.35 & 3311.55 & 49.20 & 178 & 3.62 \\
Ji176 & 3174.41 & 3230.18 & 55.77 & 167 & 2.99 \\
Ji30 & 4161.86 & 4203.83 & 41.97 & 89 & 2.12 \\
Ji31 & 2874.87 & 2934.28 & 59.41 & 150 & 2.52 \\
Ji32 & 3711.26 & 3745.53 & 34.27 & 115 & 3.36 \\
Ji33 & 3667.37 & 3714.93 & 47.56 & 87 & 1.83 \\
Ji34 & 3801.25 & 3861.91 & 60.66 & 151 & 2.49 \\
Ji35 & 4041.86 & 4085.92 & 44.06 & 91 & 2.07 \\
Ji36 & 4229.31 & 4269.44 & 40.13 & 119 & 2.97 \\
\hline
\end{tabular}

Compared with the average linear density of fractures in the upper sweet spot, the linear density of fractures in the lower sweet spot is greater in general (Figure 6). That is, bedding fractures are more developed in the lower sweet spot.

The horizontal distribution of bedding fracture linear density was, respectively, predicted for the upper and lower sweet spots according to the linear densities of bedding fractures at each borehole location. As illustrated by the horizontal distribution charts of bedding fracture linear density for the two sweet spots (Figures 7(a) and 7(b)), across Jimsar sag, the predominant development area for bedding fractures falls in the central south. The development of bedding fractures is closely associated with the sedimentary beddings, which in turn are controlled by the sedimentary microfacies. Lucaogou formation is a continental deltaic sedimentary system as a whole having received quite a lot of material supply from the south. This also associates the development of bedding fractures with sedimentary environment.
4.2. Aperture of Bedding Fractures. Cores from 13 boreholes, including Ji174, were observed in the core library of Xinjiang Oilfield (Table 1). The color, lithology, type, and oil-bearing property of these core samples, as well as the type, aperture, and filling property of the fractures therein, were described and documented in great detail. As our focus was on bedding fractures, the aperture, filling property, and oil-bearing property of the bedding fractures were finely characterized (Table 3).

Next, we are going to describe the aperture distribution of the bedding fractures. Fracture aperture, namely, the distance between fracture walls, is an important measure of the seepage and storage capacity of fractures $[49,48,50]$. Due to the release of confining pressure during sample collection, the apparent aperture of the fractures is usually greater than the true aperture of fractures underground. Hence, to obtain the true aperture of fractures, an aperture correction formula will be needed to convert the apparent fracture aperture 


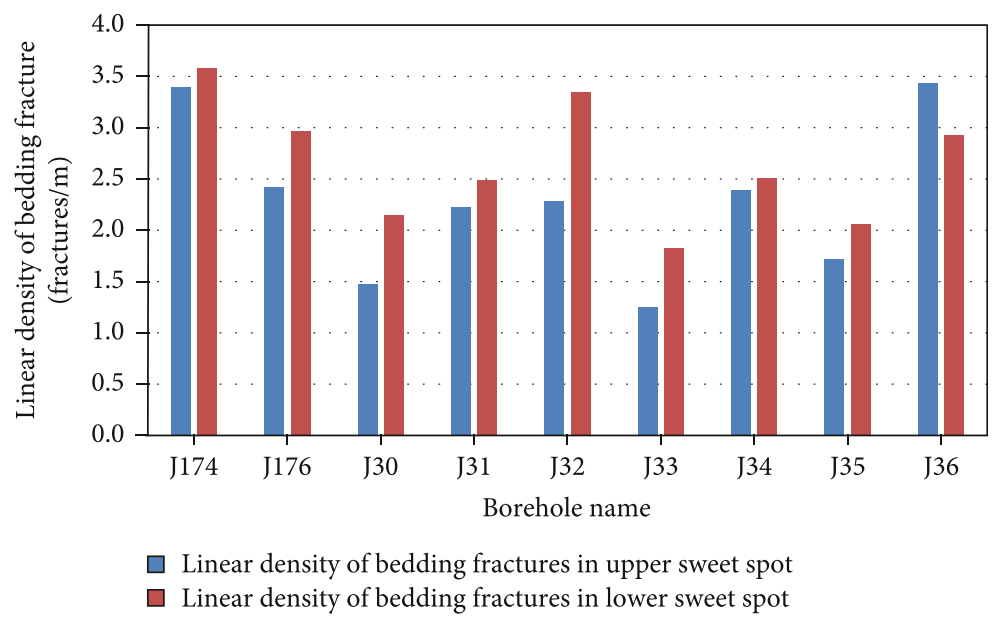

FIgURE 6: Comparing column chart of bedding fracture linear densities between the upper and lower sweet spots of Lucaogou formation in Jimsar sag.

observed in the cores into the true aperture of fractures underground. The following formula is used:

$$
b_{u}=\frac{2 b_{s} \cos ^{2} \theta}{\pi}
$$

where $b_{s}$ is the apparent aperture of fractures on the core, $b_{u}$ is the true aperture of the fractures, and $\theta$ is the angle between the fracture surface and the measured surface [51, 52]. After measuring, correcting, and counting the aperture distribution of the fractures in the cores, a fan chart of the true aperture distribution of the fractures in the study area was drawn (Figure 8). From this chart, the aperture of the fractures in the tight reservoirs of Jimsar sag is quite small as a whole, with figures mostly concentrated in the 0 $1.0 \mathrm{~mm}$ interval, which accounts for $72.13 \%$. Fractures with aperture in the $0.5-1.0 \mathrm{~mm}$ interval are the greatest contributors with a share of $48.95 \%$. Fractures with aperture greater than $1 \mathrm{~mm}$ are less developed.

4.3. Filling Property of Bedding Fractures. The filling property of fractures is an important measure of the effectiveness of fractures. As the filling degree of fractures increases, their effectiveness gradually reduces, and the formation porosity and permeability degrade.

After extensive core observation, the filling conditions of 617 bedding fractures were documented. By filling degree, these bedding fractures can be categorized as unfilled fractures, half-filled fractures, and fully filled fractures. By filling material, they can be categorized as calcite-filled, pelite-filled, asphalt-filled, pyrite-filled, others, and unfilled. Statistics discovered that the majority of the bedding fractures in Lucaogou formation are unfilled ones, accounting for $76.3 \%$ (Figures 9(a) and 9(b)). In the filled bedding fractures, the filling materials are primarily calcite, pelite, and asphalt.

4.3.1. Oil-Bearing Property of Bedding Fractures. From core observation of Ji174 and other boreholes, bedding fractures and structural fractures are important controlling factors for the oil-bearing property of a reservoir. Bedding fractures are present in the greatest quantity and with the best oilbearing property (Figures 10(a) and 10(b)). From the photographs, we can easily see that locations with densely distributed bedding fractures have good oil-bearing property. Besides, the oil-bearing can also differ from one bedding fracture to another.

Two fracture network oil-bearing patterns were recognized in the densely fractured locations: bedding fracture network and bedding-structural fracture network (Figures 10(c) and $10(\mathrm{~d})$ ). Cores under both fracture network oil-bearing patterns have good oil-bearing property. In the fracture networks, we can see more distinct oil-bearing difference among bedding fractures.

The oil-bearing grades of the observed fractures were counted. From the charts, we can easily see that bedding fractures have the best oil-bearing property whether for the oilimmersed or oil-spotted grade. Among the oil-immersed fractures, the number of bedding fractures is approximately 2.5 times that of structural fractures (Figure 11(a)). Among the oil-spotted fractures, the number of bedding fractures is approximately 1.4 times that of structural fractures (Figure 11(b)). The other types of fractures, such as water release fractures, are both poor in oil-bearing property and small in quantity. Statistics of the oil-bearing indication grades also confirms the differentiated oil-bearing among individual bedding fractures of Lucaogou formation.

\section{Discussion}

5.1. Definition of Factors Affecting the Differentiated OilBearing of Bedding Fractures. Core observation revealed differentiated oil-bearing among individual bedding fractures, as results from the differentiated influences of factors affecting the oil-bearing of these fractures. In this section, we are going to discuss factors affecting the oil-bearing of bedding fractures from the temporal and spatial perspectives. The former mainly addresses the temporal coupling between the mass hydrocarbon generation of the source rocks of Lucaogou formation and the formation of the bedding fractures therein. The latter mainly considers the spatial coupling 


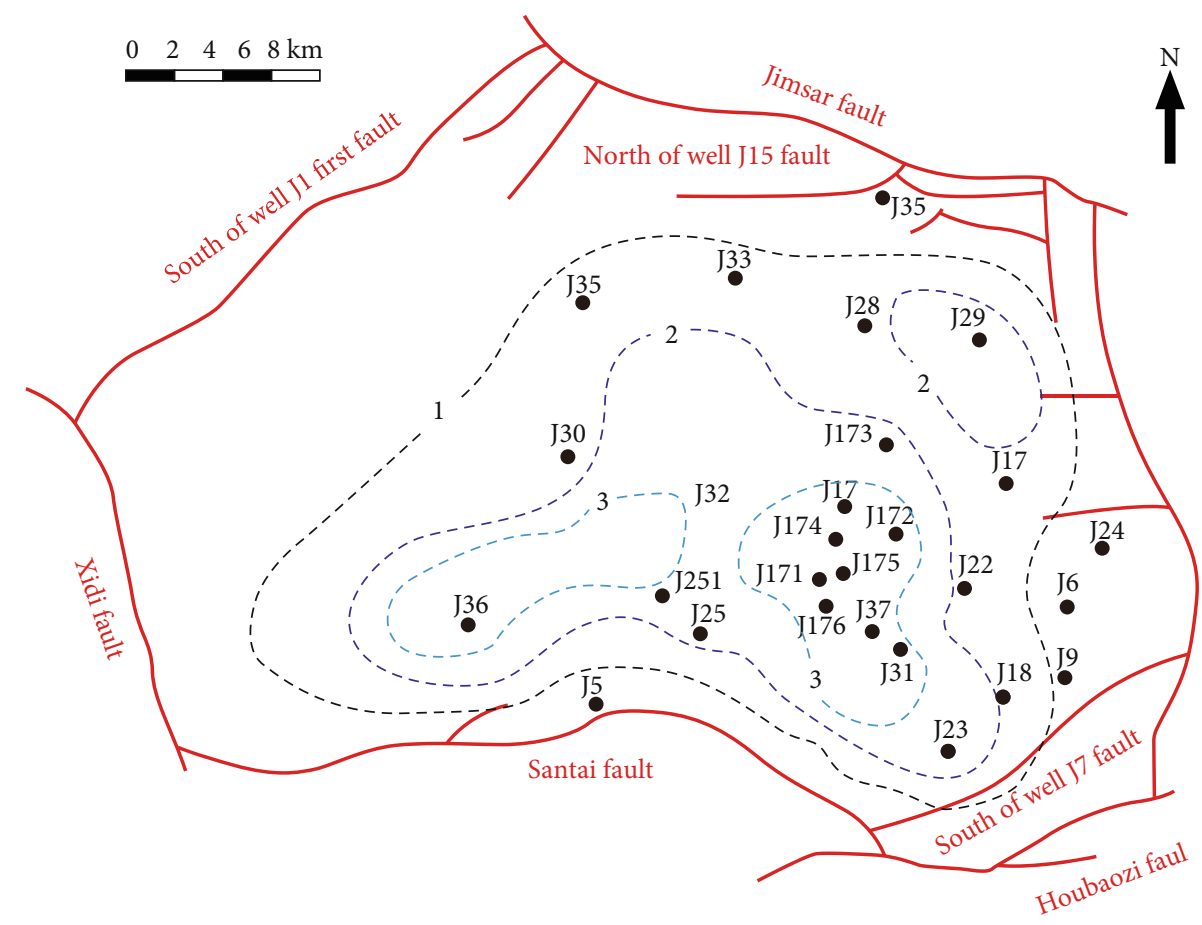

\[ \text { Fault } \]
$-\bullet$ Borehole location
$-\cdots$ Linear density contour

(a)

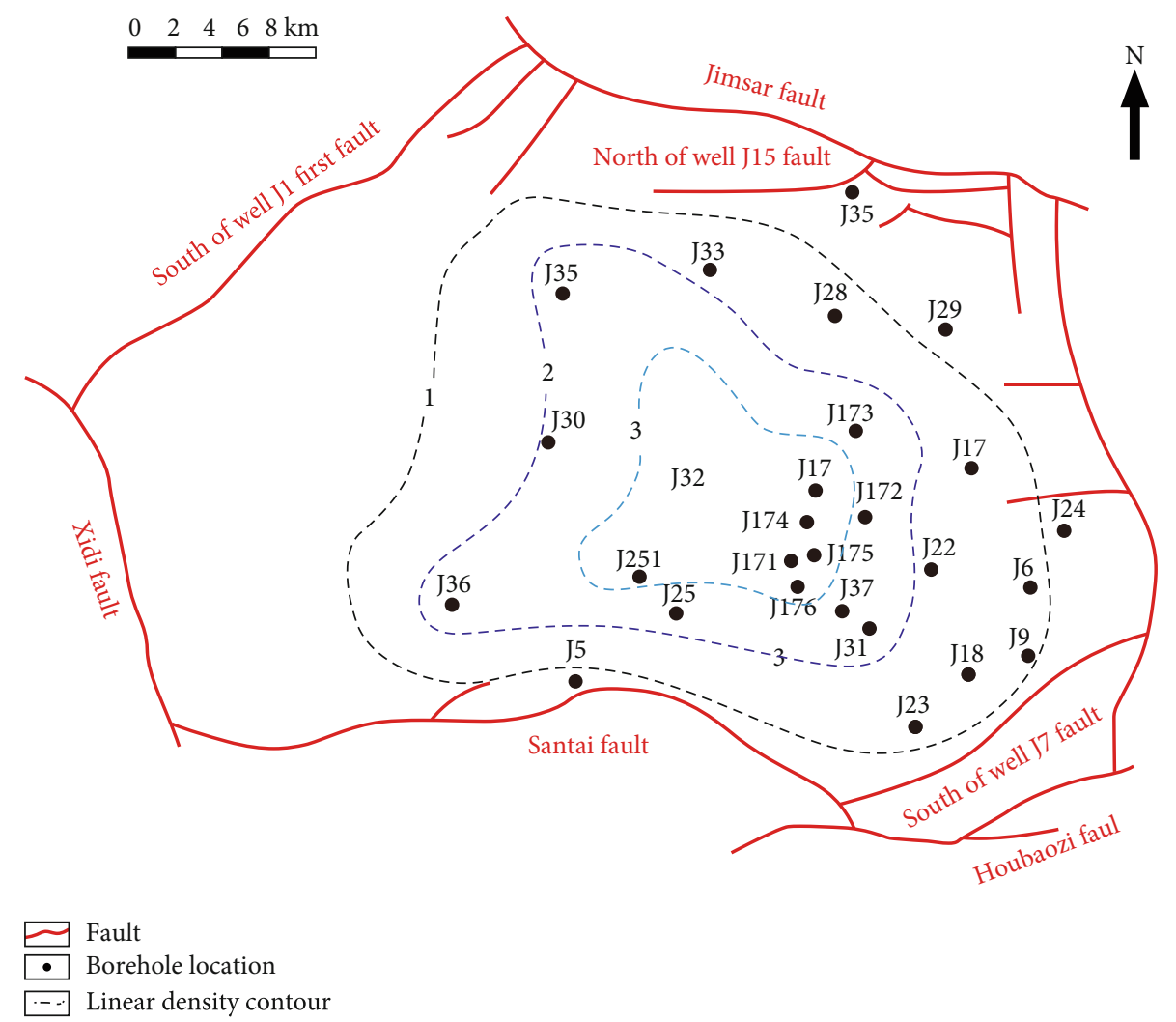

(b)

FIGURE 7: (a) Linear density prediction map of bedding fractures in the upper sweet spot of Lucaogou formation in Jimsar sag. (b) Linear density prediction map of bedding fractures in the lower sweet spot of Lucaogou formation in Jimsar sag. 
TABLE 3: Statistical table of number of bedding fractures observed in cores from Lucaogou formation in Jimsar sag.

\begin{tabular}{lcc}
\hline Borehole name & Total coring length $(\mathrm{m})$ & No. of bedding fractures \\
\hline Ji23 & 25.41 & 37 \\
Ji25 & 13.60 & 29 \\
Ji27 & 4.30 & 4 \\
Ji30 & 34.13 & 83 \\
Ji31 & 32.18 & 40 \\
Ji32 & 27.25 & 53 \\
Ji36 & 3.56 & 6 \\
Ji172 & 12.76 & 30 \\
Ji173 & 14.92 & 28 \\
Ji174 & 97.20 & 216 \\
Ji251 & 45.16 & 91 \\
Total & 310.47 & 617 \\
\hline
\end{tabular}

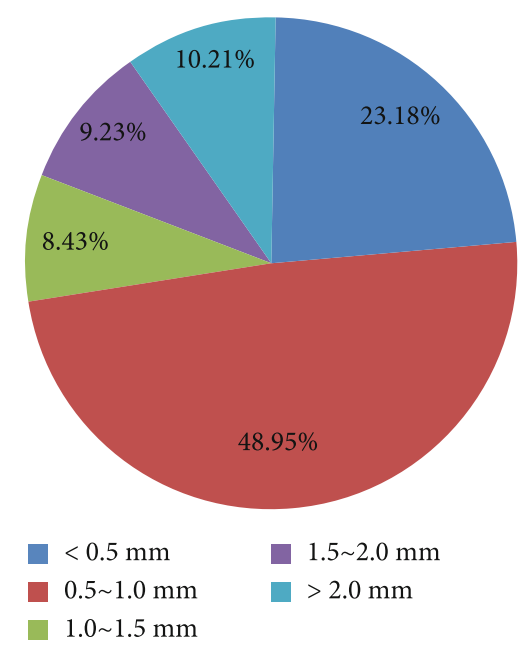

Figure 8: Fan chart of bedding fracture aperture distribution of Lucaogou formation in Jimsar sag.

between the development location of the bedding fractures and location of the source rocks.

5.2. Temporal Coupling. By temporal coupling, we refer to the matching of the mass hydrocarbon generation period of the source rocks of Lucaogou formation and the formation period of the bedding fractures therein in time. Here, our focus is on two periods: the mass hydrocarbon generation period of the source rocks of Lucaogou formation and the formation period of the bedding fractures therein. For purpose of examining the formation period of bedding fractures, fluid inclusion temperature measurement represents an effective method [19].

The fluid inclusions in the fracture-filing materials preserve a variety of information of the environment wherein the fracture filling materials formed [53-55], including the temperature at the time the inclusions were captured. By heating the inclusions and yielding their homogenization temperature, the paleotemperature of the fluids can be iden- tified. At the time when inclusions formed, their phase was just single. As the burial depth changes, so do the environmental conditions, including temperature and pressure, around the inclusions. While the external environment changes, the volume of the inclusions remains the same. Hence, the phase of the fluids inside the inclusions will change with the external environment, turning the inclusions from single phase to multiphase. By heating these multiphase inclusions until they are restored to a homogeneous liquid phase, we can yield the homogenization temperature of the inclusions, which approximately represents the temperature of the fluids contained in the inclusions when they had just formed and accordingly the temperature of the formation when the inclusions formed $[56,57]$. By combining this temperature with the burial history and geothermal history of Jimsar sag, the geological time of the inclusions, namely, the upper limit of the formation period of the fractures, can be determined. Further, by identifying the mass hydrocarbon generation period of the source rocks based on the hydrocarbon generation history of the source rocks in the basin, the coupling between the formation period of the bedding fractures and the mass hydrocarbon generation period of the source rocks in time can be investigated.

Inclusion temperature measurement specific to bedding fractures was performed on samples from 39 spots of the study area (Table 4). The bedding fracture filling materials are primarily calcite veins. The inclusions selected are typically large-volume, easily identifiable gas-liquid inclusions with distinct internal fluid phases. The inclusions are smaller than $1 \mu \mathrm{m}$ in volume. Most of the inclusions have a gas/liquid ratio between $10 \%$ and $20 \%$. They are homogeneously captured inclusions. In the samples, they are mostly elliptical or circular in shape. After they were heated to the homogenized temperature, the air bubbles disappeared and they all turned out to be liquid phase.

The homogenization temperature of the inclusions was yielded through experiment. From the homogenization temperature distribution histogram (Figure 12(a)), the homogenization temperature of the samples spans from 60 to $95^{\circ} \mathrm{C}$. For most of the samples, the homogenization temperature is between 80 and $95^{\circ} \mathrm{C}$, with the largest number of samples falling in the $85^{\circ} \mathrm{C}-90^{\circ} \mathrm{C}$ interval.

By combining the homogenization temperature of the inclusions with the paleogeotemperature of Jimsar sag, the formation period of the bedding fractures can be established. Regarding the paleogeotemperature of Jimsar sag, some authors have already attempted to reconstruct the geothermal history of this sag [19] (Figure 12(b)). From the diagram, we can easily see that the geotemperature of Lucaogou formation reached $80^{\circ} \mathrm{C}$ in Early Cretaceous. After that, it has stayed between 80 and $90^{\circ} \mathrm{C}$ most of the time. In light of the thermometric interval of the inclusions, the formation period for the majority of the bedding fractures should be in or after Early Cretaceous.

Regarding the mass hydrocarbon generation period of the source rocks of Jimsar sag, some authors have investigated the hydrocarbon generation history of Lucaogou formation based on the burial history and thermal history of Jimsar sag [58, 27] (Figure 12(c)). They discovered that 


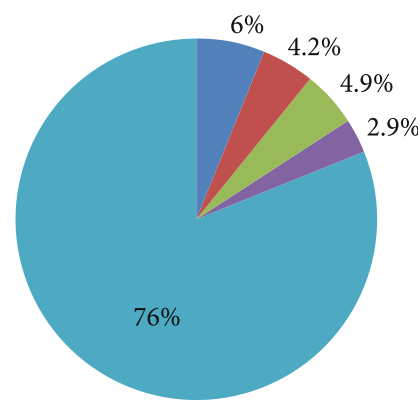

Calcite-filled Pyrite-filled

Pelite-filled Unfilled

Asphalt-filled Others

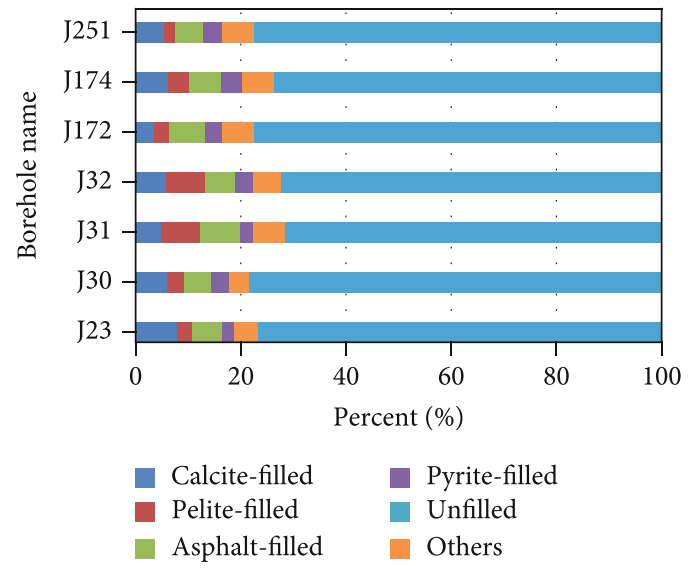

(a)

(b)

FIGURE 9: (a) Fan chart of bedding fracture filling of Lucaogou formation in Jimsar sag. (b) Stacked bar graph of bedding fracture filling condition in each borehole in Lucaogou formation in Jimsar sag.

Lucaogou formation began hydrocarbon generation in Late Triassic $(\mathrm{Ro}=0.5 \%)$ and mass hydrocarbon generation in Late Jurassic ( $\mathrm{Ro}=0.7 \%$, the portion in red). In that case, Late Jurassic should mark the beginning of mass hydrocarbon generation for the source rocks of Lucaogou formation in Jimsar sag.

By correlating the thermal history, hydrocarbon generation history of Jimsar sag with the homogenization temperature of the inclusions therein as described above, we discovered that the formation began mass hydrocarbon generation in Late Jurassic. Based on the inclusion temperature measurement result, the bedding fractures formed in or after Early Cretaceous. As Jimsar sag is simply structured, its exposure to tectonic movement has been quite modest. Hence, by matching the mass hydrocarbon generation period of the source rocks with the formation period of the bedding fractures therein, we found that the bedding fractures formed within the mass hydrocarbon generation period of the source rocks, which favored the oil-bearing of the bedding fractures.

5.3. Spatial Coupling. Regarding the factors affecting the oilbearing property of bedding fractures, apart from the temporal coupling of the formation of these fractures with mass hydrocarbon generation of the source rocks, their spatial coupling with the source rocks is also important [59, 60]. That is, the development location of the bedding fractures in the formation matches and interacts with the location of the source rocks. Source rocks normally have a high abundance of organic matter. If the bedding rocks occur close to or right inside the source rocks, they can easily accumulate oil. Hence, TOC constitutes an affecting factor. For bedding fractures far away from the source rocks, migration will be needed for them to accumulate oil. Hence, porosity, permeability, and even the size of pore throat are affecting factors. Here, we are going to discuss the spatial coupling between bedding fractures and source rocks from the perspective of TOC, porosity, permeability, and pore throat.

5.3.1. Determination of the Oil-Bearing Indicator of Bedding Fractures. Regarding the oil-bearing property of bedding fractures, through core observation, we can easily tell how good the oil-bearing property is for individual fractures [61, 62]. However, as the number of cores available is limited, so is the number of bedding fractures observable therein. To investigate the oil-bearing property of the bedding fractures in the entire Lucaogou formation, we have to find a proper indicator. Through correlation in terms of time, we established that in Lucaogou formation, mass hydrocarbon generation occurred before the formation of bedding fractures. In that case, the oil and gas generated should have been stored in the pores of the formation. Furthermore, after extensive core observation, we also found that if the oil-bearing property of a bedding fracture is good, that of the surrounding formation matrix will be good, too. So the oil content of the formation matrix would be an ideal indirect indicator for the oil content of the bedding fractures developed therein. In the absence of coupling with other fractures, we suggest that the greater the oil content of the matrix, the better the oil-bearing property of the bedding fractures developed therein. As the oil contained in bedding fractures is free petroleum, here we used chloroform asphalt " $A$ " to represent the oil-bearing of bedding fractures. Chloroform asphalt " $\mathrm{A}$ " is the organic matter dissolved and extracted from rocks using chloroform. Generally, the mass percentage of chloroform asphalt " $\mathrm{A}$ " in the rock is used to represent the content of chloroform asphalt "A."

5.3.2. TOC. After analyzing the TOC levels of the rock samples [63], we discovered that all three types of rocks are high in organic matter, with average TOC of $2.83 \%$. For dolomite, the TOC range is $0.39 \%-4.65 \%$ with an average of $2.27 \%$. For siltstone, the TOC range is $0.57 \%-4.16 \%$ with an average of $2.47 \%$. For mudstone, the TOC range is $0.91 \%-8.50 \%$ with an average of $3.99 \%$ (Figure 13). Among the three types of rocks, the mudstone has the highest TOC.

By examining the relationship between chloroform asphalt " $\mathrm{A}$ " and TOC, we can easily see that overall, the chloroform asphalt " $\mathrm{A}$ " of the formation matrix (the oil content of the strata) is positively correlated with TOC. That is, the larger the TOC, the larger the chloroform asphalt "A," 


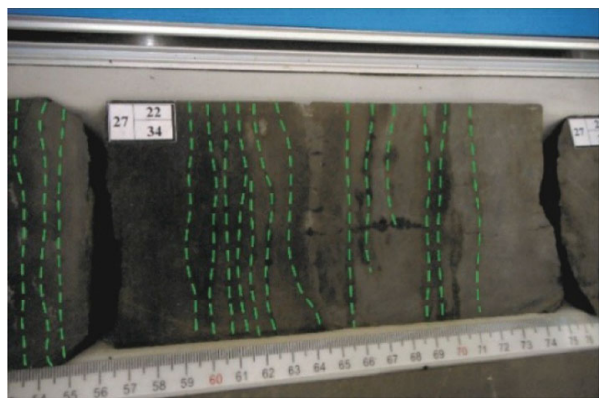

(a)

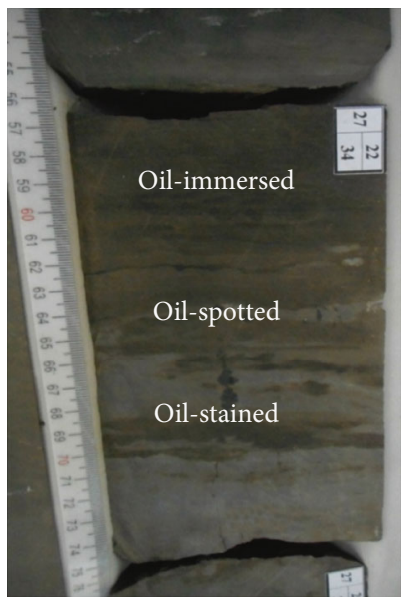

(c)

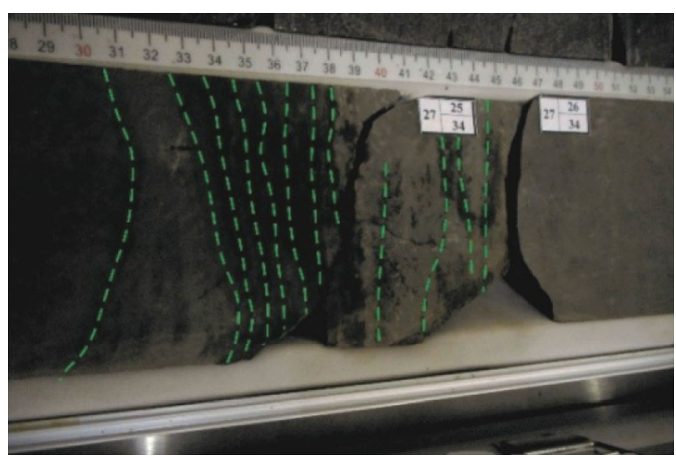

(b)

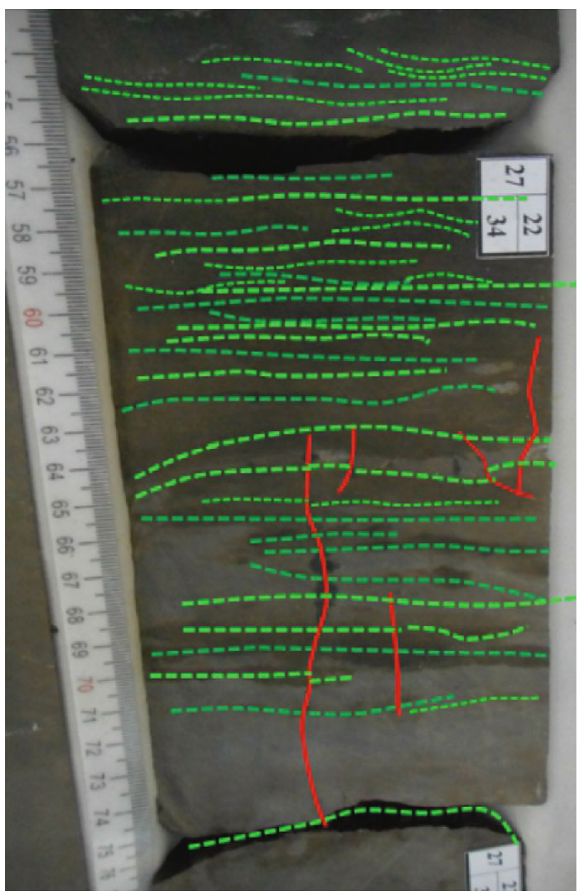

(d)

FiguRE 10: Core photographs of Lucaogou formation in Jimsar sag. (a) Ji174, 3305.8 m; (b) Ji174, 3307.2 m; (c) core photograph of Ji174, $3305.1 \mathrm{~m}$; (d) interpreted core photograph of Ji174, $3305.1 \mathrm{~m}$.

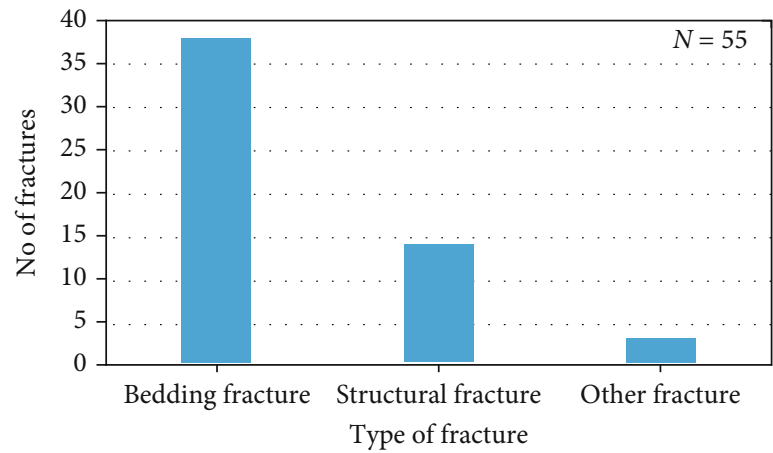

(a)

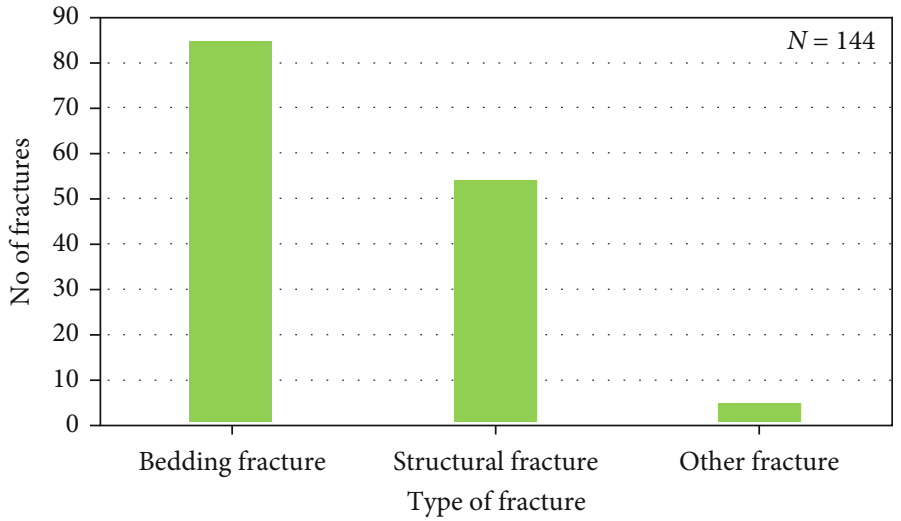

(b)

FIGURE 11: (a) Statistical chart of number of oil-immersed fractures in cores from Lucaogou formation in Jimsar sag; (b) statistical chart of number of oil-spotted fractures in cores from Lucaogou formation in Jimsar sag. 
TABLE 4: Fluid inclusion parameter table of bedding fracture fillers in Lucaogou formation.

\begin{tabular}{|c|c|c|c|c|c|}
\hline SN & Host mineral & Origin & Type & Gas/liquid ratio (\%) & Homogenization Temp. $\left({ }^{\circ} \mathrm{C}\right)$ \\
\hline 1 & Calcite & Secondary & Liquid inclusion & 10 & 86 \\
\hline 2 & Calcite & Secondary & Liquid inclusion & 15 & 85.6 \\
\hline 3 & Calcite & Secondary & Liquid inclusion & 10 & 74 \\
\hline 4 & Calcite & Secondary & Liquid inclusion & 15 & 87 \\
\hline 5 & Calcite & Secondary & Liquid inclusion & 10 & 81 \\
\hline 6 & Calcite & Secondary & Liquid inclusion & 10 & 88.2 \\
\hline 7 & Calcite & Secondary & Liquid inclusion & 15 & 85.9 \\
\hline 8 & Calcite & Secondary & Liquid inclusion & 5 & 80.3 \\
\hline 9 & Calcite & Secondary & Liquid inclusion & 10 & 89 \\
\hline 10 & Calcite & Secondary & Liquid inclusion & 10 & 87.2 \\
\hline 11 & Calcite & Secondary & Liquid inclusion & 15 & 92 \\
\hline 12 & Calcite & Secondary & Liquid inclusion & 15 & 82.2 \\
\hline 13 & Calcite & Secondary & Liquid inclusion & 20 & 91 \\
\hline 14 & Calcite & Secondary & Liquid inclusion & 10 & 62 \\
\hline 15 & Calcite & Secondary & Liquid inclusion & 20 & 94.2 \\
\hline 16 & Calcite & Secondary & Liquid inclusion & 15 & 87.5 \\
\hline 17 & Calcite & Secondary & Liquid inclusion & 10 & 80.8 \\
\hline 18 & Calcite & Secondary & Liquid inclusion & 15 & 89.5 \\
\hline 19 & Calcite & Secondary & Liquid inclusion & 15 & 90.5 \\
\hline 20 & Calcite & Secondary & Liquid inclusion & 10 & 72.5 \\
\hline 21 & Calcite & Secondary & Liquid inclusion & 15 & 88 \\
\hline 22 & Calcite & Secondary & Liquid inclusion & 10 & 82.6 \\
\hline 23 & Calcite & Secondary & Liquid inclusion & 10 & 87.3 \\
\hline 24 & Calcite & Secondary & Liquid inclusion & 15 & 86.5 \\
\hline 25 & Calcite & Secondary & Liquid inclusion & 10 & 84 \\
\hline 26 & Calcite & Secondary & Liquid inclusion & 15 & 91 \\
\hline 27 & Calcite & Secondary & Liquid inclusion & 10 & 89.1 \\
\hline 28 & Calcite & Secondary & Liquid inclusion & 15 & 79.4 \\
\hline 29 & Calcite & Secondary & Liquid inclusion & 10 & 85.5 \\
\hline 30 & Calcite & Secondary & Liquid inclusion & 10 & 83 \\
\hline 31 & Calcite & Secondary & Liquid inclusion & 15 & 93 \\
\hline 32 & Calcite & Secondary & Liquid inclusion & 10 & 83.6 \\
\hline 33 & Calcite & Secondary & Liquid inclusion & 5 & 61.5 \\
\hline 34 & Calcite & Secondary & Liquid inclusion & 10 & 89.3 \\
\hline 35 & Calcite & Secondary & Liquid inclusion & 10 & 76.2 \\
\hline 36 & Calcite & Secondary & Liquid inclusion & 10 & 88.1 \\
\hline 37 & Calcite & Secondary & Liquid inclusion & 15 & 82 \\
\hline 38 & Calcite & Secondary & Liquid inclusion & 10 & 86.3 \\
\hline 39 & Calcite & Secondary & Liquid inclusion & 15 & 89 \\
\hline
\end{tabular}

accordingly the higher the oil content of the formation and the better the oil-bearing property of the bedding fractures developed therein (Figure 14). However, in the diagram, we also observed three anomalous spots (as marked by red ellipses) that show very high TOC but very low chloroform asphalt "A" (Figure 14). Moreover, the rocks of all three spots are mudstone and dolomite, which are both a type of rock with low overall porosity. Further analysis revealed that the porosity of all three spots is very low. The porosity of the dolomite sample is $4.33 \%$. That of the two mudstone samples is $1.25 \%$ and $3.18 \%$, respectively. The low chloroform asphalt "A" of these spots is caused by their low porosity and limited storage spaces inside themselves, which limit their respective oil content. However, in Lucaogou formation, mudstone is the main source rock with great hydrocarbon generation potential [64]. All these spots have very high TOC. They have great hydrocarbon generation potential and the ability to generate hydrocarbon continuously. Hence, for the oil- 


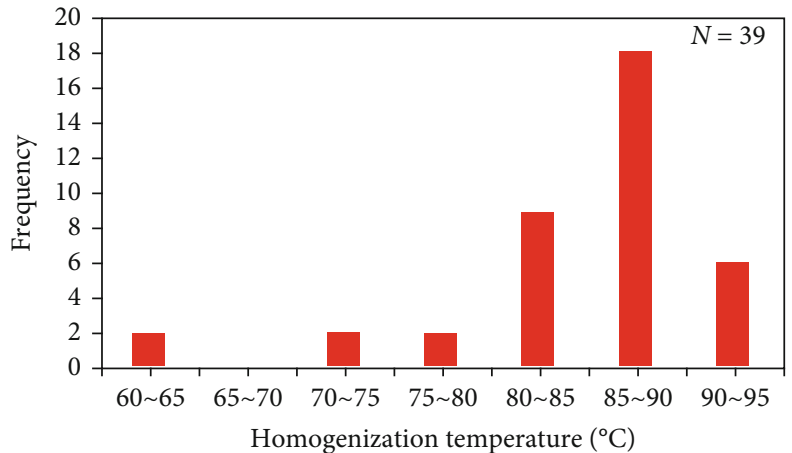

(a)

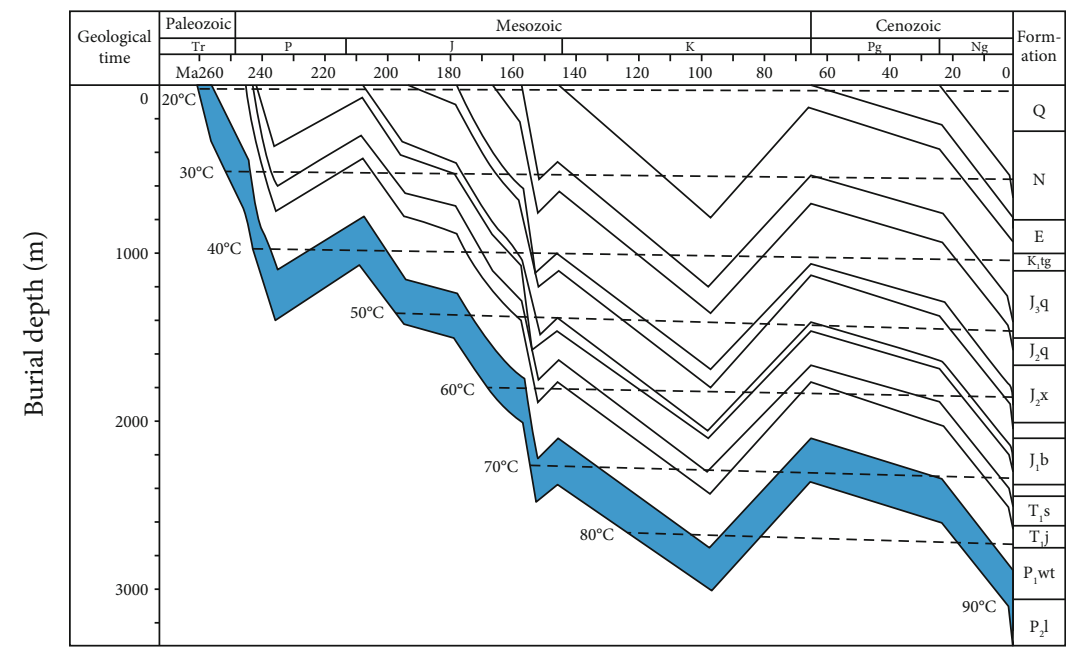

-- Temperature contour
- Formation boundary
Lucaogou formation

(b)

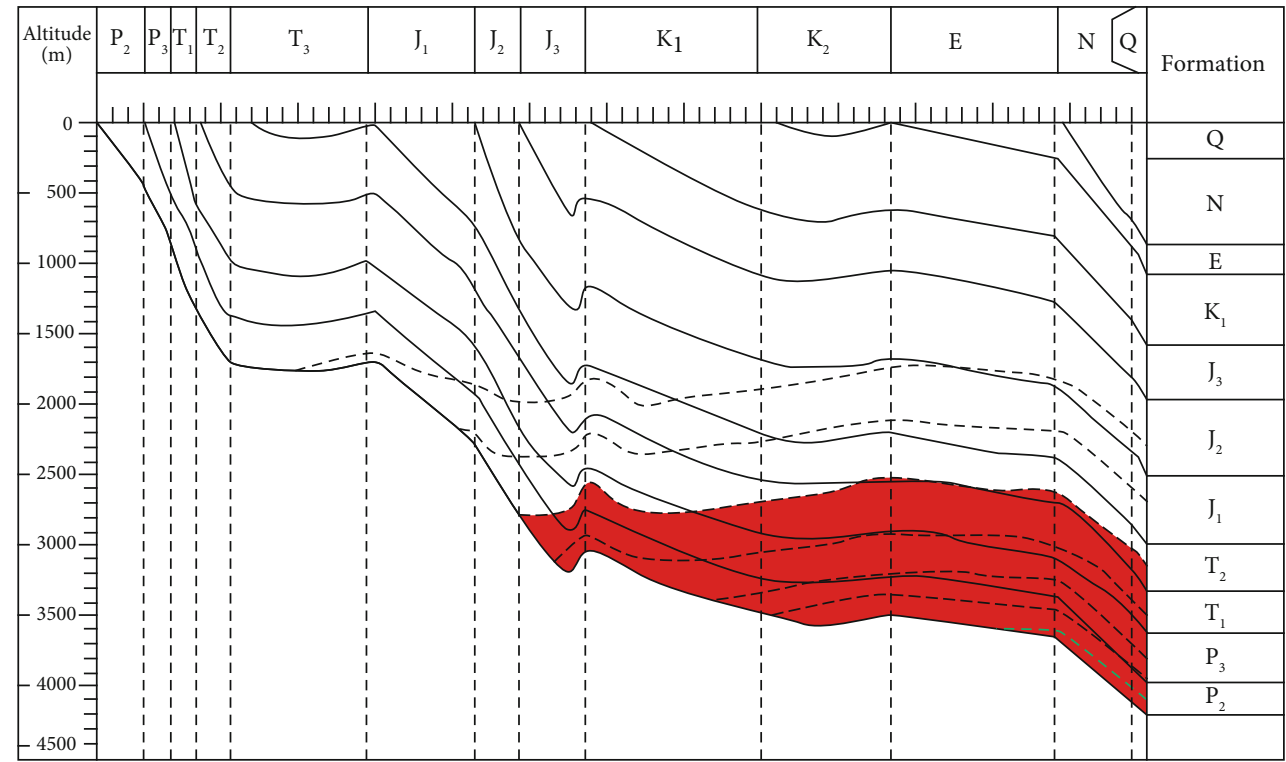

(c)

FIGURE 12: (a) Homogenization temperature distribution histogram of samples from Lucaogou formation. (b) Burial history and thermal history diagram of Jimsar sag. (c) Burial history and hydrocarbon generation history diagram of Jimsar sag. 


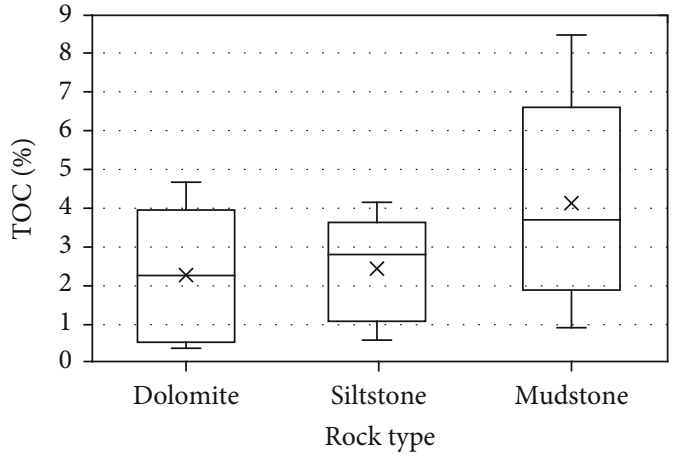

FIGURE 13: Box diagram of TOC value distribution of rock samples from Lucaogou formation.

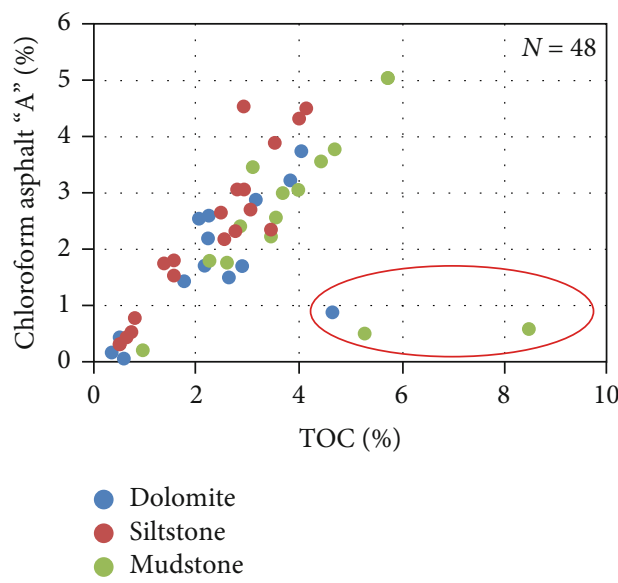

FIGURE 14: Relation diagram of chloroform asphalt " $A$ " and TOC value of rock samples from Lucaogou formation.

bearing of bedding fractures, high TOC is a good contributor. In this sense, TOC is positively correlated with the oilbearing property of bedding fractures.

5.3.3. Porosity. Pores are important storage spaces for tight oil. In this paper, we also examined the relationship between porosity and the oil-bearing property of bedding fractures. From the porosity distribution diagram, we can also see that dolomite, siltstone, and mudstone all exhibit a fairly broad porosity range, with siltstone having the highest average porosity, followed by dolomite and mudstone (Figure 15). For siltstone, the porosity range is $3.29 \%-19.60 \%$ with an average of $11.02 \%$. For dolomite, the porosity range is $3.64 \%-15.71 \%$ with an average of $8.28 \%$. For mudstone, the porosity range is $0.69 \%-14.90 \%$ with an average of $6.09 \%$.

As discovered from analysis above, porosity affects the level of chloroform asphalt "A." In the present study, we also investigated the relationship between chloroform asphalt " $\mathrm{A}$ " and porosity (Figure 16). From the relationship diagram, we can see that overall, porosity is positively correlated with chloroform asphalt "A." That is, the larger the porosity, the larger the chloroform asphalt "A," accordingly the higher the oil content of the formation matrix and the better the oil-bearing property of the bedding fractures developed therein. After further analysis, we also discovered a couple

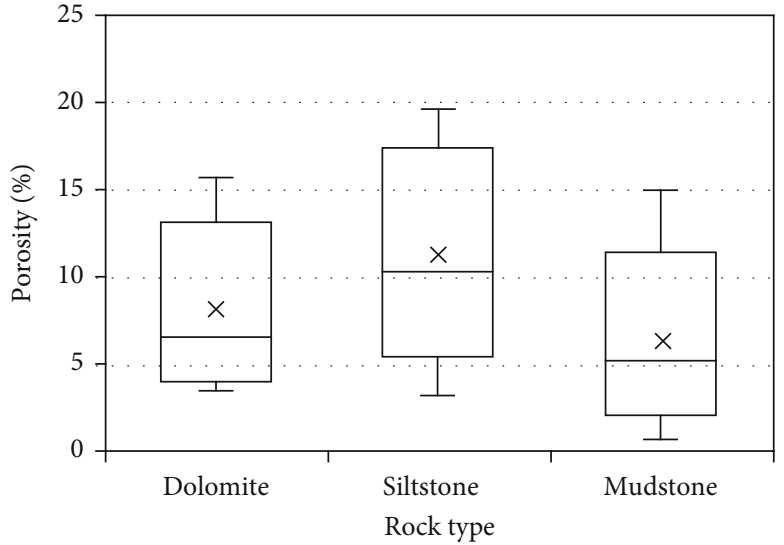

FIgURE 15: Box diagram of porosity distribution of samples from Lucaogou formation.

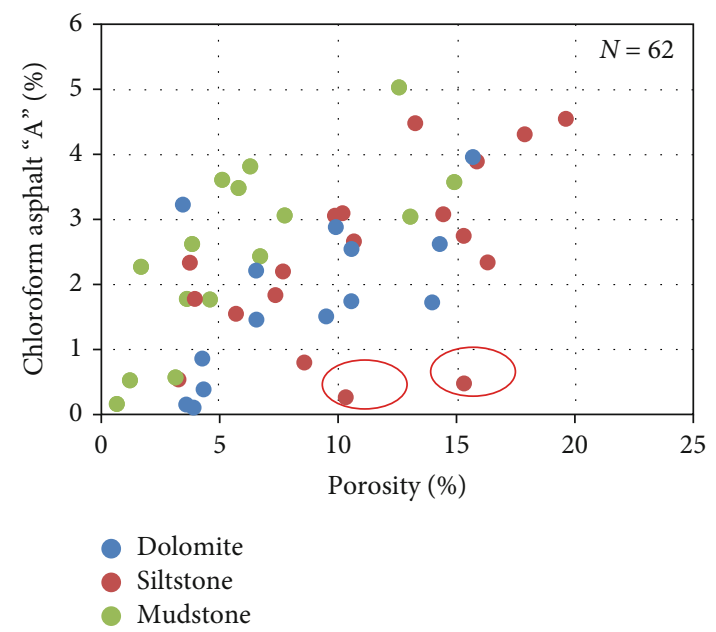

FIgURE 16: Relation diagram of chloroform asphalt " $A$ " and porosity of rock samples from Lucaogou formation.

of anomalous spots (as marked by red ellipses) that have fairly high porosity but very low chloroform asphalt "A." A closer look at the TOC of these spots revealed that the TOC of both spots is very low- $0.61 \%$ and $0.57 \%$, respectively, (Figure 16). This indicates that the hydrocarbon generation potential of these spots is very low, which explains why these anomalous spots should exist. The TOC is low. Their own hydrocarbon generation potential is low. The oil and gas generated could not fill up their own pores, and the tight oil outside did not migrate in. Accordingly, the oil-bearing property of the bedding fractures developed in the formation will be poor. Existence of these anomalous spots suggests that porosity is essentially controlled by TOC.

At large, the oil-bearing property of bedding fractures is positively correlated with the formation porosity, since pores are the storage spaces for tight oil. As most of the rocks in Lucaogou formation have a level of hydrocarbon generation potential and the tight oil generated will fill up the whole pores, high-porosity bedding fractures there will have good oil-bearing property. However, this does not apply to all 


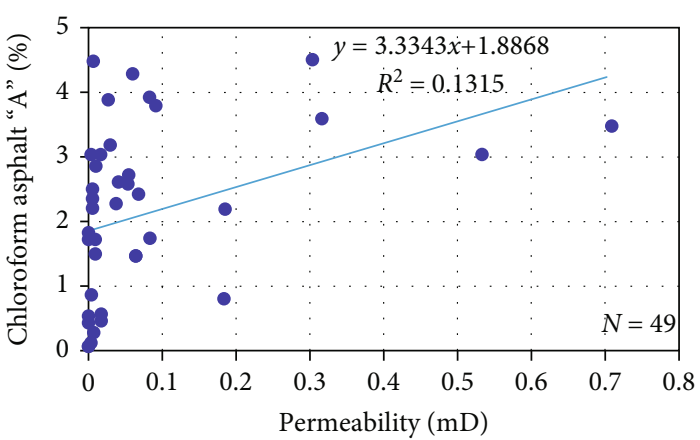

(a)

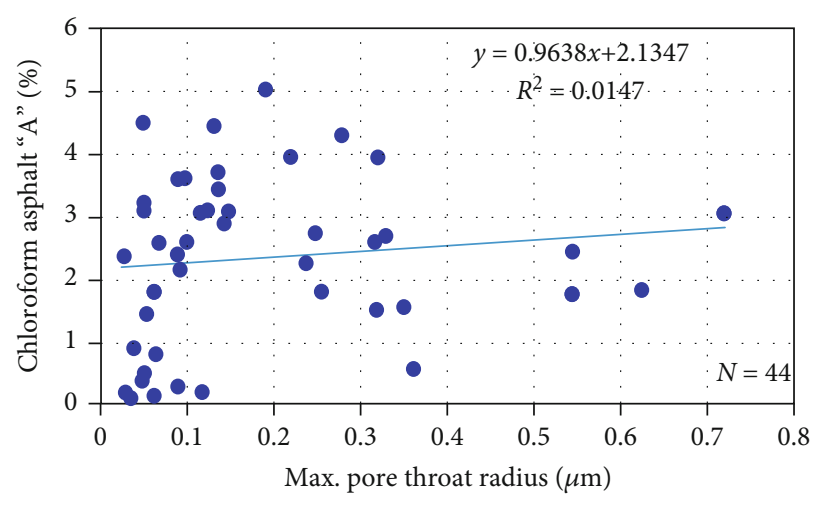

(b)

FiguRE 17: (a) Relation diagram of chloroform asphalt "A" and permeability of rock samples from Lucaogou formation. (b) Relation diagram of chloroform asphalt "A" and maximum pore throat radius of rock samples from Lucaogou formation.

bedding fractures. If the host formation has very high porosity but very low TOC, the bedding fractures will have to rely on migration to bear oil. Then, porosity and pore throat will make a difference to the oil-bearing of the bedding fractures. However, tight oil migration is not likely to happen in Lucaogou formation given its tight strata.

5.3.4. Permeability and Pore Throat. Permeability and pore throat are key parameters affecting tight oil migration. In strata with large porosity but small TOC, for tight oil to migrate into the bedding fractures, permeability and pore throat will become key factors affecting the oil-bearing of these bedding fractures. The relationship of chloroform asphalt "A" with permeability (Figure 17(a)) and with maximum pore throat radius (Figure 17(b)) was, respectively, analyzed. From the scatter diagrams, we can see that the correlation coefficient between permeability and chloroform asphalt " $\mathrm{A}$ " is 0.1315 , and that between maximum pore throat radius and chloroform asphalt " $\mathrm{A}$ " is 0.0147 . Chloroform asphalt " $\mathrm{A}$ " is almost not correlated with either permeability or pore throat. That is, permeability and pore throat make little difference to the oil-bearing of bedding fractures.

After examining the permeability and pore throat data, we discovered that samples with permeability smaller than $0.1 \mathrm{mD}$ account for more than $90 \%$. After excluding anomalous values, the average permeability is $0.07 \mathrm{mD}$, suggesting a typical tight reservoir. For the majority of the samples, the maximum pore throat radius is smaller than $0.4 \mu \mathrm{m}$. According to the pore throat classification criteria for lowpermeability sandstone $[65,66]$ (Table 5 ), the pore throats are basically all microthroats.

According to the mercury injection statistics, for the rock samples tested, the average displacement pressure is $9.22 \mathrm{MPa}$; the average saturation median pressure is $31.72 \mathrm{MPa}$; the average maximum pore throat radius is $0.18 \mu \mathrm{m}$; the average median radius is $0.08 \mu \mathrm{m}$. These figures strongly confirm that tight oil migration is not likely to happen in Lucaogou formation unless there is a huge pressure difference. Hence, the influence of permeability and pore throat on the oil-bearing of bedding fractures is quite modest. Only when the formation porosity is large and the TOC is
TABLE 5: Classification criteria for pore and throat in low permeability sandstone [66].

\begin{tabular}{lc}
\hline Throat size rating & Prevailing throat radius $(\mu \mathrm{m})$ \\
\hline Coarse throat & $>4$ \\
Medium throat & $2-4$ \\
Fine throat & $1-2$ \\
Tiny throat & $0.5-1$ \\
Microthroat & $0.025-0.5$ \\
Adsorption throat & $<0.025$ \\
\hline
\end{tabular}

small will the bedding fractures rely on migration to bear oil. Accordingly, only then will permeability and pore throat become the deciding factors for the oil-bearing of bedding fractures.

Among the factors considered for spatial coupling, for TOC, the larger the formation TOC, the better the oilbearing of the bedding fractures. For porosity, subject to the TOC, if the TOC is adequate, the larger the porosity, the larger the chloroform asphalt "A," accordingly the higher the oil content of the strata and the better the oil-bearing property of the bedding fractures developed therein. If the TOC is inadequate and the porosity is large, the bedding fractures will have to rely on migration to bear oil. In that case, permeability and pore throat will make a difference to the oil-bearing of the bedding fractures. However, as the strata of Lucaogou formation are tight, tight oil migration is not likely to happen there. Hence, in terms of spatial coupling, TOC is the main controlling factor for the oil-bearing property of bedding fractures.

\section{Conclusions}

(1) Bedding fractures are extensively present in Lucaogou formation tight oil reservoir in Jimsar sag. In fact, they are the most frequently found type of fractures there. Statistics and calculation show that the linear density of the bedding fractures is $2.23 / \mathrm{m}$ for the upper sweet spot and $2.65 / \mathrm{m}$ for the lower sweet spot. 
By comparison, bedding fractures are more developed in the lower sweet spot

(2) The favorable area for the development of bedding fractures lies in the central south of the sag. Overall, these fractures occur in parallel to the formation boundary. Their aperture is quite small. Most of them are unfilled fractures. For the filled fractures, the filling materials mainly include calcite, petite, and asphalt. Among the few types of fractures found in Lucaogou formation, bedding fractures have the best oil-bearing property, but the oil-bearing can differ from one bedding fracture to another

(3) The factors affecting the differentiated oil-bearing of the bedding fractures include temporal coupling and spatial coupling. In terms of temporal coupling, the majority of the bedding fractures in Lucaogou formation formed in or after Early Cretaceous, while the source rocks of this formation began mass hydrocarbon generation in Late Jurassic. By matching these two periods, we suggest that the bedding fractures formed within the mass hydrocarbon generation period of the source rocks, which favored the oilbearing of these fractures. In terms of spatial coupling, the influencing factors include TOC, porosity, permeability, and pore throat, with TOC being the main controlling factor

\section{Data Availability}

All data, models, and code generated or used during the study appear in the submitted article.

\section{Conflicts of Interest}

The authors declare that they have no conflicts of interest.

\section{Authors' Contributions}

Jia Lu and Chen Zhang contributed equally to this work.

\section{Acknowledgments}

This work is financially supported by the grants from the National Natural Science Foundation of China (No. 42002050) and the China Postdoctoral Science Foundation Funded Project (No. 2020M680815).

\section{References}

[1] Z. Caineng, Y. Zhi, Z. Rukai et al., "Progress in China's unconventional oil \& gas exploration and development and theoretical technologies," Acta Geologica Sinica-English Edition, vol. 89, no. 3, pp. 938-971, 2015.

[2] H. Wang, F. Ma, X. Tong et al., "Assessment of global unconventional oil and gas resources," Petroleum Exploration and Development, vol. 43, no. 6, pp. 925-940, 2016.

[3] Y. Song, Z. Li, Z. Jiang, Q. Luo, D. Liu, and Z. Gao, "Progress and development trend of unconventional oil and gas geolog- ical research," Petroleum Exploration and Development, vol. 44, no. 4, pp. 675-685, 2017.

[4] X. Tong, G. Zhang, Z. Wang et al., "Distribution and potential of global oil and gas resources," Petroleum Exploration and Development, vol. 45, no. 4, pp. 779-789, 2018.

[5] X. Guo, Y. Li, R. Liu, and Q. Wang, "Characteristics and controlling factors of micropore structures of the Longmaxi Shale in the Jiaoshiba area, Sichuan Basin," Natural Gas Industry B, vol. 1, no. 2, pp. 165-171, 2014.

[6] Y. Cai, D. Liu, Z. Pan, Y. Yao, and C. Li, "Mineral occurrence and its impact on fracture generation in selected Qinshui Basin coals: an experimental perspective," International Journal of Coal Geology, vol. 150-151, pp. 35-50, 2015.

[7] G. Aghli, R. Moussavi-Harami, and R. Mohammadian, "Reservoir heterogeneity and fracture parameter determination using electrical image logs and petrophysical data (a case study, carbonate Asmari Formation, Zagros Basin, SW Iran)," Petroleum Science, vol. 17, no. 1, pp. 51-69, 2020.

[8] J. Shi, L. Zeng, X. Zhao, Y. Zhang, and J. Wang, "Characteristics of natural fractures in the upper Paleozoic coal bearing strata in the southern Qinshui Basin, China: implications for coalbed methane (CBM) development," Marine and Petroleum Geology, vol. 113, p. 104152, 2020.

[9] S. Bergbauer and D. D. Pollard, "A new conceptual foldfracture model including prefolding joints, based on the Emigrant Gap anticline, Wyoming," Geological Society of America Bulletin, vol. 116, no. 3, pp. 294-307, 2004.

[10] O. Lacombe, N. Bellahsen, and F. Mouthereau, "Fracture patterns in the Zagros Simply Folded Belt (Fars, Iran): constraints on early collisional tectonic history and role of basement faults," Geological Magazine, vol. 148, no. 5-6, pp. 940-963, 2011.

[11] J. F. Gale, S. E. Laubach, J. E. Olson, P. Eichhuble, and A. Fall, "Natural fractures in shale: a review and new observationsNatural fractures in shale: a review and new observations," $A A P G$ Bulletin, vol. 98, no. 11, pp. 2165-2216, 2014.

[12] Q. Wang, W. Liu, L. Pei et al., "Hydrocarbon generation from calcium stearate: insights from closed-system pyrolysis," Marine and Petroleum Geology, vol. 126, article 104923, 2021.

[13] J. Parnell, P. Carey, and B. Monson, "Fluid inclusion constraints on temperatures of petroleum migration from authigenic quartz in bitumen veins," Chemical Geology, vol. 129, no. 3-4, pp. 217-226, 1996.

[14] D. Feng and D. Chen, "Authigenic carbonates from an active cold seep of the northern South China Sea: new insights into fluid sources and past seepage activity," Deep Sea Research Part II: Topical Studies in Oceanography, vol. 122, pp. 74-83, 2015.

[15] T. P. Harding and J. D. Lowell, "Structural styles, their platetectonic habitats, and hydrocarbon traps in petroleum provinces," AAPG Bulletin, vol. 63, no. 7, pp. 1016-1058, 1979.

[16] B. Sanford, F. Thompson, and G. McFall, "Plate tectonics-a possible controlling mechanism in the development of hydrocarbon traps in southwestern Ontario," Bulletin of Canadian Petroleum Geology, vol. 33, no. 1, pp. 52-71, 1985.

[17] Z. Wu and J. Yin, "Fracturing behaviors of FRP-strengthened concrete structures," Engineering Fracture Mechanics, vol. 70, no. 10, pp. 1339-1355, 2003.

[18] X. Zhang, R. G. Jeffrey, and M. Thiercelin, "Deflection and propagation of fluid-driven fractures at frictional bedding 
interfaces: a numerical investigation," Journal of Structural Geology, vol. 29, no. 3, pp. 396-410, 2007.

[19] D. Liu, C. Zhang, Z. Pan et al., "Natural fractures in carbonaterich tight oil reservoirs from the Permian Lucaogou Formation, southern Junggar Basin, NW China: insights from fluid inclusion microthermometry and isotopic geochemistry," Marine and Petroleum Geology, vol. 119, p. 104500, 2020.

[20] X. Zhang and R. G. Jeffrey, "Reinitiation or termination of fluid-driven fractures at frictional bedding interfaces," Journal of Geophysical Research: Solid Earth, vol. 113, no. B8, 2008.

[21] X. Chang, Y. Shan, Z. Zhang, C. Tang, and Z. Ru, "Behavior of propagating fracture at bedding interface in layered rocks," Engineering Geology, vol. 197, pp. 33-41, 2015.

[22] H. P. Lee, J. E. Olson, J. Holder, J. F. Gale, and R. D. Myers, "The interaction of propagating opening mode fractures with preexisting discontinuities in shale," Journal of Geophysical Research: Solid Earth, vol. 120, no. 1, pp. 169-181, 2015.

[23] L. Jijun, W. Weiming, C. Qun, S. Yinglin, Y. Xintong, and T. Shansi, "Impact of hydrocarbon expulsion efficiency of continental shale upon shale oil accumulations in eastern China," Marine and Petroleum Geology, vol. 59, pp. 467479, 2015.

[24] H. Liu, S. Zhang, G. Song et al., "A discussion on the origin of shale reservoir inter-laminar fractures in the Shahejie Formation of Paleogene, Dongying depression," Journal of Earth Science, vol. 28, no. 6, pp. 1064-1077, 2017.

[25] M. Zheng, J. Li, X. Wu et al., "Physical modeling of oil charging in tight reservoirs: a case study of Permian Lucaogou Formation in Jimsar Sag, Junggar Basin, NW China," Petroleum Exploration and Development, vol. 43, no. 2, pp. 241-250, 2016.

[26] C. Zhang, D. Zhu, Q. Luo et al., "Major factors controlling fracture development in the Middle Permian Lucaogou Formation tight oil reservoir, Junggar Basin, NW China," Journal of Asian Earth Sciences, vol. 146, pp. 279-295, 2017.

[27] Y. Yang, L. Qiu, M. Wan et al., "Depositional model for a salinized lacustrine basin: the permian Lucaogou formation, Jimsar sag, Junggar Basin, NW China," Journal of Asian Earth Sciences, vol. 178, pp. 81-95, 2019.

[28] Y. Yang, J. Yang, G. Yang et al., "New research progress of Jurassic tight oil in central Sichuan Basin, SW China," Petroleum Exploration and Development, vol. 43, no. 6, pp. 954964, 2016.

[29] H. Yang, X. Liang, X. Niu, S. Feng, and Y. You, "Geological conditions for continental tight oil formation and the main controlling factors for the enrichment: a case of Chang $7 \mathrm{Mem}$ ber, Triassic Yanchang Formation, Ordos Basin, NW China," Petroleum Exploration and Development, vol. 44, no. 1, pp. 11-19, 2017.

[30] H. Dou, S. Ma, C. Zou, and S. Yao, “Threshold pressure gradient of fluid flow through multi-porous media in low and extralow permeability reservoirs," Science China Earth Sciences, vol. 57, no. 11, pp. 2808-2818, 2014.

[31] H. Bai, X. Pang, L. Kuang et al., "Hydrocarbon expulsion potential of source rocks and its influence on the distribution of lacustrine tight oil reservoir, Middle Permian Lucaogou Formation, Jimsar Sag, Junggar Basin, Northwest China," Journal of Petroleum Science and Engineering, vol. 149, pp. 740-755, 2017.

[32] Q. Wang, Y. Qin, W. Jia, Y. Wang, W. Zhang, and P. A. Peng, "Density and viscosity of tight oil from Yanchang Formation,
Ordos Basin, China and the geochemical controls," Petroleum Science and Technology, vol. 36, no. 16, pp. 1298-1304, 2018.

[33] G. Xiu e, "Relation between the productivity and the degree of development of the fractures in low porosity and low permeability sandshale reservoirs," Natural Gas Industry, vol. 23, no. 5, pp. 41-43, 2003.

[34] O. Pal, B. Zoghbi, and W. Razzaq, "Characterization of unconventional reservoir for development and production: an integrated approach," in Proceedings SPE Middle East Unconventional Resources Conference and Exhibition2015, Society of Petroleum Engineers, Muscat, Oman, January 2015.

[35] W. Hu, Y. Wei, and J. Bao, "Development of the theory and technology for low permeability reservoirs in China," Petroleum Exploration and Development, vol. 45, no. 4, pp. 685697, 2018.

[36] Y. Yang, L. Qiu, Y. Cao, C. Chen, D. Lei, and M. Wan, "Reservoir quality and diagenesis of the Permian Lucaogou Formation tight carbonates in Jimsar Sag, Junggar Basin, west China," Journal of Earth Science, vol. 28, no. 6, pp. 1032-1046, 2017.

[37] Y. Zhi, H. Lianhua, L. Senhu et al., "Geologic characteristics and exploration potential of tight oil and shale oil in Lucaogou Formation in Jimsar sag," China Petroleum Exploration, vol. 23, no. 4, pp. 76-85, 2018.

[38] Y. Feng, R. G. Coleman, G. Tilton, and X. Xiao, "Tectonic evolution of the west Junggar region, Xinjiang, China," Tectonics, vol. 8, no. 4, pp. 729-752, 1989.

[39] Z. Xixi, R. S. Coe, Z. Yaoxiu, W. HaoRuo, and W. Jie, "New paleomagnetic results from northern China: collision and suturing with Siberia and Kazakhstan," Tectonophysics, vol. 181, no. 1-4, pp. 43-81, 1990.

[40] S.-L. Li, X.-H. Yu, C.-P. Tan, R. Steel, and X.-F. Hu, "Jurassic sedimentary evolution of southern Junggar Basin: implication for palaeoclimate changes in northern Xinjiang Uygur Autonomous Region, China," Journal of Palaeogeography, vol. 3, no. 2, pp. 145-161, 2014.

[41] K. Lichun, W. Xiatian, G. Xuguang, C. Qiusheng, and J. Xiyu, "Geological characteristics and exploration practice of tight oil of Lucaogou Formation in Jimsar Sag," Xinjiang Petroleum Geology, vol. 36, no. 6, p. 1, 2019.

[42] Y. Su, M. Zha, X. Ding et al., "Petrographic, palynologic and geochemical characteristics of source rocks of the Permian Lucaogou formation in Jimsar Sag, Junggar Basin, NW China: origin of organic matter input and depositional environments," Journal of Petroleum Science and Engineering, vol. 183, p. 106364, 2019.

[43] X. Ding, C. Gao, M. Zha, H. Chen, and Y. Su, "Depositional environment and factors controlling $\beta$-carotane accumulation: a case study from the Jimsar Sag, Junggar Basin, northwestern China," Palaeogeography, Palaeoclimatology, Palaeoecology, vol. 485, pp. 833-842, 2017.

[44] C. Liu, K. Liu, X. Wang, L. Wu, and Y. Fan, "Chemostratigraphy and sedimentary facies analysis of the Permian Lucaogou Formation in the Jimusaer Sag, Junggar Basin, NW China: implications for tight oil exploration," Journal of Asian Earth Sciences, vol. 178, pp. 96-111, 2019.

[45] S. Yin, C. Han, Z. Wu, and Q. Li, "Developmental characteristics, influencing factors and prediction of fractures for a tight gas sandstone in a gentle structural area of the Ordos Basin, China," Journal of Natural Gas Science and Engineering, vol. 72, p. 103032, 2019. 
[46] G. Feng, X. Wang, M. Wang, and Y. Kang, "Experimental investigation of thermal cycling effect on fracture characteristics of granite in a geothermal-energy reservoir," Engineering Fracture Mechanics, vol. 235, p. 107180, 2020.

[47] A. Ouenes, "Practical application of fuzzy logic and neural networks to fractured reservoir characterization," Computers \& Geosciences, vol. 26, no. 8, pp. 953-962, 2000.

[48] D. J. Sanderson and C. W. Nixon, "The use of topology in fracture network characterization," Journal of Structural Geology, vol. 72, pp. 55-66, 2015.

[49] Z. Lianbo and L. Xiang-Yang, "Fractures in sandstone reservoirs with ultra-low permeability: a case study of the Upper Triassic Yanchang Formation in the Ordos Basin, China," AAPG Bulletin, vol. 93, no. 4, pp. 461-477, 2009.

[50] L. Zeng, W. Lyu, J. Li et al., "Natural fractures and their influence on shale gas enrichment in Sichuan Basin, China," Journal of Natural Gas Science and Engineering, vol. 30, pp. 1-9, 2016.

[51] C.-H. Lee, B.-W. Deng, and J.-L. Chang, "A continuum approach for estimating permeability in naturally fractured rocks," Engineering Geology, vol. 39, no. 1-2, pp. 71-85, 1995.

[52] H. L. Ramandi, P. Mostaghimi, and R. T. Armstrong, "Digital rock analysis for accurate prediction of fractured media permeability," Journal of Hydrology, vol. 554, pp. 817-826, 2017.

[53] P. Nazariyan Samani, M. Mirshahani, Z. Zamani, and M. Bahremandi, "Carbonate cements investigation in PermoTriassic Dalan-Kangan reservoirs: case study in Persian Gulf, Iran," International Journal of Petroleum and Geoscience Engineering, vol. 3, no. 2, pp. 108-115, 2015.

[54] K. Spikes, "Overview of rock property relationships and characterization methods for selected oil and gas shales in North America," Geohorizons, vol. 17, no. 1, pp. 18-25, 2012.

[55] K. Azmy and N. J. Blamey, "Source of diagenetic fluids from fluid-inclusion gas ratios," Chemical Geology, vol. 347, pp. 246-254, 2013.

[56] A. M. Van den Kerkhof and U. F. Hein, "Fluid inclusion petrography," Lithos, vol. 55, no. 1-4, pp. 27-47, 2001.

[57] Y.-F. Yang, N. Li, and Y.-J. Chen, "Fluid inclusion study of the Nannihu giant porphyry Mo-W deposit, Henan Province, China: implications for the nature of porphyry ore-fluid systems formed in a continental collision setting," Ore Geology Reviews, vol. 46, pp. 83-94, 2012.

[58] X. Ding, J. Qu, A. Imin et al., "Organic matter origin and accumulation in tuffaceous shale of the lower Permian Lucaogou Formation, Jimsar Sag," Journal of Petroleum Science and Engineering, vol. 179, pp. 696-706, 2019.

[59] L. Cai, G. Xiao, S. Lu, J. Wang, and Z. Wu, "Spatial-temporal coupling between high-quality source rocks and reservoirs for tight sandstone oil and gas accumulations in the Songliao Basin, China," International Journal of Mining Science and Technology, vol. 29, no. 3, pp. 387-397, 2019.

[60] W. Zhao, X. Wang, S. Hu et al., "Hydrocarbon generation characteristics and exploration prospects of Proterozoic source rocks in China," Science China Earth Sciences, vol. 62, no. 6, pp. 909-934, 2019.

[61] L. Zeng, C. Gao, J. Qi, Y. Wang, L. Li, and X. Qu, "The distribution rule and seepage effect of the fractures in the ultra-low permeability sandstone reservoir in east Gansu Province, Ordos Basin," Science in China Series D: Earth Sciences, vol. 51, no. S2, pp. 44-52, 2008.
[62] S. Su, Z. Jiang, S. Xuanlong et al., "The effects of shale pore structure and mineral components on shale oil accumulation in the Zhanhua Sag, Jiyang Depression, Bohai Bay Basin, China," Journal of Petroleum Science and Engineering, vol. 165, pp. 365-374, 2018.

[63] T. Barth and K. Bjørlykke, "Organic acids from source rock maturation: generation potentials, transport mechanisms and relevance for mineral diagenesis," Applied Geochemistry, vol. 8, no. 4, pp. 325-337, 1993.

[64] Q. Zhen, S. Zhensheng, D. Dazhong et al., "Geological characteristics of source rock and reservoir of tight oil and its accumulation mechanism: a case study of Permian Lucaogou Formation in Jimusar sag, Junggar Basin," Petroleum Exploration and Development, vol. 43, no. 6, pp. 1013-1024, 2016.

[65] P. Li, M. Zheng, H. Bi, S. Wu, and X. Wang, "Pore throat structure and fractal characteristics of tight oil sandstone: a case study in the Ordos Basin, China," Journal of Petroleum Science and Engineering, vol. 149, pp. 665-674, 2017.

[66] S. Lu, J. Li, P. Zhang et al., "Classification of microscopic porethroats and the grading evaluation on shale oil reservoirs," Petroleum Exploration and Development, vol. 45, no. 3, pp. 452-460, 2018. 